OPEN ACCESS

Edited by:

Omar Orellana,

University of Chile, Chile

Reviewed by:

Irina Artsimovitch,

The Ohio State University,

United States

Harald Putzer,

UMR 8261 Expression Génétique

Microbienne, France

*Correspondence:

Scarlet S. Shell

sshell@wpi.edu

TORCID:

Diego A. Vargas-Blanco orcid.org/0000-0002-3559-2902

Scarlet S. Shell

orcid.org/0000-0003-1136-1728

Specialty section:

This article was submitted to

Microbial Physiology and Metabolism,

a section of the journal

Frontiers in Microbiology

Received: 28 May 2020

Accepted: 11 August 2020

Published: 09 September 2020

Citation:

Vargas-Blanco DA and Shell SS (2020) Regulation of mRNA Stability

During Bacterial Stress Responses.

Front. Microbiol. 11:2111.

doi: 10.3389/fmicb.2020.02111

\section{Regulation of mRNA Stability During Bacterial Stress Responses}

\author{
Diego A. Vargas-Blanco ${ }^{1 \dagger}$ and Scarlet S. Shell ${ }^{1,2 *+}$ \\ ${ }^{1}$ Department of Biology and Biotechnology, Worcester Polytechnic Institute, Worcester, MA, United States, ${ }^{2}$ Program \\ in Bioinformatics and Computational Biology, Worcester Polytechnic Institute, Worcester, MA, United States
}

Bacteria have a remarkable ability to sense environmental changes, swiftly regulating their transcriptional and posttranscriptional machinery as a response. Under conditions that cause growth to slow or stop, bacteria typically stabilize their transcriptomes in what has been shown to be a conserved stress response. In recent years, diverse studies have elucidated many of the mechanisms underlying mRNA degradation, yet an understanding of the regulation of mRNA degradation under stress conditions remains elusive. In this review we discuss the diverse mechanisms that have been shown to affect mRNA stability in bacteria. While many of these mechanisms are transcript-specific, they provide insight into possible mechanisms of global mRNA stabilization. To that end, we have compiled information on how mRNA fate is affected by RNA secondary structures; interaction with ribosomes, RNA binding proteins, and small RNAs; RNA base modifications; the chemical nature of $5^{\prime}$ ends; activity and concentration of RNases and other degradation proteins; mRNA and RNase localization; and the stringent response. We also provide an analysis of reported relationships between mRNA abundance and mRNA stability, and discuss the importance of stress-associated mRNA stabilization as a potential target for therapeutic development.

\footnotetext{
Keywords: ribonucleic acid, stress response, carbon starvation, nutrient starvation, hypoxia, mRNA degradation, mRNA stability, bacteria
}

\section{INTRODUCTION}

Bacterial adaptation to stress is orchestrated by complex responses to specific environmental stimuli, capable of rapidly regulating transcription, transcript degradation, and translation, which increases the organism's survival opportunities. Historically, regulation mechanisms for transcriptional and translational pathways have been the most studied, providing insight into the genes and protein products needed for bacterial adaptation to unfavorable growth environments. These findings have been key for our understanding of bacterial biology, allowing us, for example, to develop tools to tune bacterial machinery for biotechnology processes (such as Tao et al., 2011; Courbet et al., 2015; Daeffler et al., 2017; Martinez et al., 2017; Riglar et al., 2017), and to discover and develop new antibacterial drugs (for example, Yarmolinsky and Haba, 1959; Wolfe and Hahn, 1965; Maggi et al., 1966; Olson et al., 2011). However, the role of RNA degradation in stress responses is not well understood. 
Modulation of mRNA degradation has been associated with various stress conditions in bacteria, such as temperature changes, growth rate, nutrient starvation, and oxygen limitation (see Table 1). Transcript stability - also referred as mRNA or transcript half-life - was shown to be globally altered in response to some stressors, while in other cases, genespecific modulation of transcript stability contributes to specific expression changes that bacteria need to adapt to and survive in new environments (Figure 1).

In this review, we will discuss a range of reported situations in which bacterial mRNA stability is modulated in response to various stress conditions, with a focus on known and suspected mechanisms underlying such regulation. We will also discuss the ways in which known gene-specific mechanisms shape our thinking on the unanswered question of how mRNA pools are globally stabilized in response to energy stress. Furthermore, we will discuss the ways in which regulation of mRNA stability in clinically relevant bacteria, such as Mycobacterium tuberculosis, shape their responses to the host environment.

\section{RNases AND OTHER DEGRADATION PROTEINS}

\section{The Degradosome}

RNA degradation is carried out by a wide range of RNases, enzymes with strong activities and relatively low specificities toward their targets (reviewed in Carpousis, 2007). There are two main types of RNases: endonucleases and exonucleases. The former cleave RNA sequences at internal points, while the latter carry out nucleolytic attacks from either end of the RNA chain (deemed $5^{\prime}$ or $3^{\prime}$ exonucleases based on their enzymatic directionality). Some bacteria possess both $5^{\prime}$ and $3^{\prime}$ exonucleases - M. tuberculosis and Mycobacterium smegmatis, for example - while others such as E. coli have only $3^{\prime}$ exonucleases.

With respect to RNA degradation systems, E. coli is perhaps the most studied organism. In fact, it was in $E$. coli that a multiprotein complex, deemed the degradosome (Figure 2), was first reported (Carpousis et al., 1994; Py et al., 1994). In E. coli, the main degradosome components are two RNases (RNase E and PNPase), a DEAD-box RNA helicase (RhlB), and a glycolytic enzyme (enolase) (Carpousis et al., 1994; Py et al., 1994; Marcaida et al., 2006; Carpousis, 2007). RhlB facilitates RNase activity by unwinding stem-loops within RNA targets (Py et al., 1996). Both RNases carry out RNA degradation (Mohanty and Kushner, 2000; Deutscher, 2006; Unciuleac and Shuman, 2013). Moreover, in this bacterium the C-terminal region of RNase $\mathrm{E}$ acts as a scaffold for other degradosome components (Kido et al., 1996; Vanzo et al., 1998; Lopez et al., 1999; Morita et al., 2004). However, not all of the degradosome components are well defined or have known roles. For example, enolase is suspected to have a regulatory role in mRNA degradation under low phosphosugar levels (Morita et al., 2004; Chandran and Luisi, 2006) and anaerobic conditions (Murashko and Lin-Chao, 2017).

While RNases can degrade RNA substrates on their own, it has been suggested that degradosomes increase the efficiency of RNA degradation, for example by facilitating processing of structures such as stem-loops and repeated extragenic palindromic sequences (Newbury et al., 1987; McLaren et al., 1991; Py et al., 1996). Alteration of the degradosome components leads to changes in transcriptome stability; for example, deletion of RhlB in E. coli results in longer mRNA halflives (Bernstein et al., 2004). Similarly, mRNA stability is dramatically increased when the arginine-rich RNA binding region or the scaffolding region of RNase $\mathrm{E}$ are deleted (Kido et al., 1996; Ow et al., 2000). While the RNA degradosome of $E$. coli has been extensively studied, the composition and function of degradosomes in other gram-negatives and in grampositives may differ, and new studies are still uncovering this information. In the Firmicute Bacillus subtilis, there is no RNase E homolog. Instead, RNase Y serves as a degradosome scaffold for PNPase, the helicase CshA (Lehnik-Habrink et al., 2010), phosphofructokinase (Commichau et al., 2009), and RNase J1 and RNase J2 - two bifunctional enzymes with both endonucleolytic and $5^{\prime}-3^{\prime}$ exoribonuclease activity (Even et al., 2005; Shahbabian et al., 2009; Mathy et al., 2010; Durand et al., 2012). Interestingly, the B. subtilis degradosome interactions have been shown mainly by bacterial 2-hybrid assays and immunoprecipitation of complexes stabilized by formaldehyde crosslinking (Commichau et al., 2009; Lehnik-Habrink et al., 2010), in contrast to the E. coli degradosome which can be immunoprecipitated without a crosslinking agent (Carpousis et al., 1994; Py et al., 1994, 1996). This suggests that B. subtilis degradosomes could be more transient in nature. A recent report on the Actinomycete $M$. tuberculosis provided insight into its elusive degradosome structure, which appears to be composed of RhlE (an RNA helicase), PNPase, RNase E, and RNase J (Plocinski et al., 2019). Overall, the degradosome is considered to be the ultimate effector of bulk mRNA degradation in bacterial cells, but it has also been implicated in regulating the stability of specific mRNAs and sRNAs, as will be discussed in later sections. For further details on the degradosome, we encourage reading the following reviews (Carpousis, 2007; Bandyra et al., 2013; Ait-Bara and Carpousis, 2015; Cho, 2017; Tejada-Arranz et al., 2020).

\section{An Overview of RNase Regulation}

There are multiple ways in which transcript levels can be regulated. Alteration of mRNA steady-state abundance is ultimately a consequence of changes in transcription, changes in mRNA half-life, or both. In the process of mRNA degradation, the roles of different RNases may be defined in part by their preferred cleavage sequences. In Staphylococcus aureus, RNase Y cleavage is usually in the $\mathrm{R} \downarrow W$ sequence, near $A U$ rich regions (Khemici et al., 2015). This pattern seems to be conserved in B. subtilis (Shahbabian et al., 2009). Furthermore, in these two gram-positive organisms, RNase Y cleavage appears to be influenced by proximity to a secondary structure. In E. coli, RNase E cleaves single-stranded RNA with a strong preference for the +2 sites in $\mathrm{RN} \downarrow$ AU (Mackie, 1992; McDowall et al., 1994), or in $\mathrm{RN} \downarrow \mathrm{WUU}$ in Salmonella enterica (Chao et al., 2017). In M. smegmatis, a strong preference for cleavage $5^{\prime}$ of cytidines was detected in a transcriptome-wide RNA cleavage analysis (Martini et al., 2019). RNase E could be 
TABLE 1 | Transcriptome-wide studies on mRNA half-life in bacteria.

\begin{tabular}{|c|c|c|c|c|c|}
\hline Organism & Growth/stress condition & $\begin{array}{l}\text { Response to stress/condition } \\
\text { (transcriptome stability) }\end{array}$ & $\begin{array}{l}\text { mRNA quantification } \\
\text { method }\end{array}$ & $\begin{array}{l}\text { Correlation between mRNA } \\
\text { abundance and half-life }\end{array}$ & References \\
\hline $\begin{array}{l}\text { Bacillus cereus ATCC } \\
\text { 10987, ATCC } 14579\end{array}$ & Exponential phase & - & RNA-seq & Positive & Kristoffersen et al., 2012 \\
\hline Bacillus subtilis & Early stationary phase & Stable $^{*}$ & Microarray & Not calculated & Hambraeus et al., 2003 \\
\hline $\begin{array}{l}\text { Chlamydia trachomatis } \\
\text { biovars: trachoma, } \\
\text { lymphogranuloma } \\
\text { venereum }\end{array}$ & Mid-phase stage of developmental cycle & - & RNA-seq & None & Ferreira et al., 2017 \\
\hline Escherichia coli & Exponential phase & - & Microarray & Negative & Bernstein et al., 2002 \\
\hline Escherichia coli & Exponential phase & - & Microarray & Not calculated & Selinger et al., 2003 \\
\hline \multirow[t]{4}{*}{ Escherichia coli } & $0.1 \mathrm{~h}^{-1}$ growth rate & \multirow[t]{4}{*}{ Stabilization at slower growth rates } & \multirow[t]{4}{*}{ Microarray } & \multirow[t]{4}{*}{ Negative } & \multirow[t]{4}{*}{ Esquerre et al., 2014, 2015} \\
\hline & $0.2 \mathrm{~h}^{-1}$ growth rate & & & & \\
\hline & $0.4 \mathrm{~h}^{-1}$ growth rate & & & & \\
\hline & $0.63 \mathrm{~h}^{-1}$ growth rate & & & & \\
\hline \multirow[t]{2}{*}{ Escherichia coli } & Exponential phase & \multirow[t]{2}{*}{ Stabilization in stationary phase } & \multirow[t]{2}{*}{ RNA-seq } & \multirow[t]{2}{*}{ Positive } & \multirow[t]{2}{*}{ Chen et al., 2015} \\
\hline & Stationary phase & & & & \\
\hline \multirow[t]{3}{*}{ Escherichia coli } & Exponential phase & \multirow[t]{3}{*}{ Destabilization in $\triangle$ csrA51 } & \multirow[t]{3}{*}{ Microarray } & \multirow[t]{3}{*}{ Negative } & \multirow[t]{3}{*}{ Esquerre et al., 2016} \\
\hline & Exponential phase $(\Delta c s r D)$ & & & & \\
\hline & Exponential phase $(\Delta c s r A 51)$ & & & & \\
\hline \multirow[t]{2}{*}{ Escherichia coli } & Exponential phase & \multirow[t]{2}{*}{ Stabilization in Ksm } & \multirow[t]{2}{*}{ RNA-seq } & \multirow[t]{2}{*}{ None for either condition ${ }^{\dagger}$} & \multirow[t]{2}{*}{ Moffitt et al., 2016} \\
\hline & $\begin{array}{l}\text { Exponential phase + Ksm (initiation } \\
\text { inhibitor) }\end{array}$ & & & & \\
\hline $\begin{array}{l}\text { Escherichia coli, } \\
\text { Lactococcus lactis }\end{array}$ & Multiple f $^{\ddagger}$ & $\begin{array}{l}\text { Stabilization at low growth rates } \\
\text { and stress }\end{array}$ & $\begin{array}{l}\text { Microarray, Nylon } \\
\text { membrane-based } \\
\text { macroarray }\end{array}$ & Negative & Nouaille et al., 2017 \\
\hline \multirow[t]{2}{*}{ Escherichia coli } & Exponential phase & \multirow[t]{2}{*}{ Stabilization in $r n e \Delta M T S$} & \multirow[t]{2}{*}{ Microarray } & \multirow[t]{2}{*}{ Not calculated } & \multirow[t]{2}{*}{ Hadjeras et al., 2019} \\
\hline & Exponential phase (rne $\Delta M T S)$ & & & & \\
\hline \multirow[t]{4}{*}{ Escherichia coli } & Exponential phase & \multirow[t]{4}{*}{ Stabilization in stress } & \multirow[t]{4}{*}{ Microarray } & \multirow[t]{4}{*}{ Negative $^{\dagger}$} & \multirow[t]{4}{*}{ Morin et al., 2020} \\
\hline & Glucose exhaustion & & & & \\
\hline & Acetate consumption & & & & \\
\hline & Carbon starvation & & & & \\
\hline \multirow[t]{3}{*}{ Lactococcus lactis } & Exponential phase & Stabilization at slower growth rates & Nylon membrane-based & Negative & Redon et al., 2005a,b \\
\hline & Deceleration phase & & & None & \\
\hline & Starvation phase & & & Positive & \\
\hline Lactococcus lactis & Isoleucine limitation, $0.11 \mathrm{~h}^{-1}$ growth rate & Stabilization at slower growth rates & $\begin{array}{l}\text { Nylon membrane-based } \\
\text { macroarrays }\end{array}$ & Negative & Dressaire et al., 2013 \\
\hline & Isoleucine limitation, $0.51 \mathrm{~h}^{-1}$ growth rate & & & & \\
\hline & Isoleucine limitation, $0.8 \mathrm{~h}^{-1}$ growth rate & & & & \\
\hline
\end{tabular}




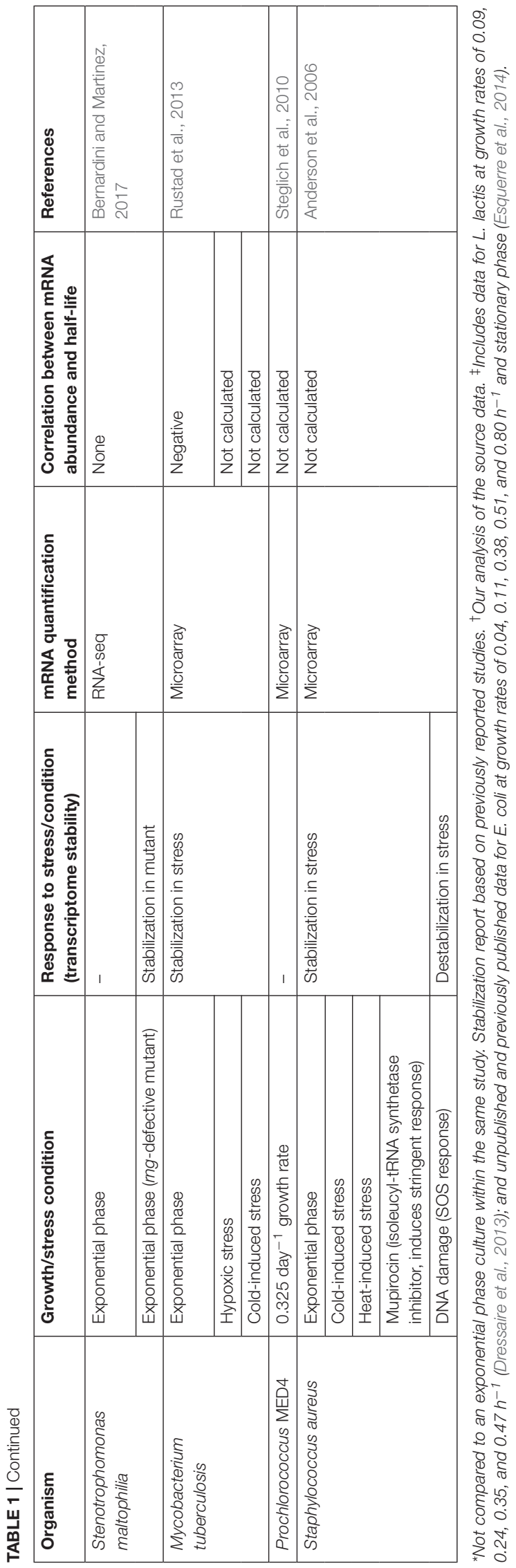

responsible for these cleavage events, given its major role in mycobacteria, however, we cannot yet exclude the possibility that they are produced by another endonuclease. In contrast, RNase III in E. coli has optimal activity on double-stranded RNA, where the cleavage site is specified by both positive and negative sequence and secondary structure determinants (Pertzev and Nicholson, 2006). While the preferred cleavage sites of various RNases seem highly represented in the mRNA pool, some transcripts are more resistant to cleavage than others, indicating the presence of mechanisms that regulate not only bulk RNA stability, but also differential stabilities among transcripts.

Studies of various mRNAs have identified multiple features that confer protection against RNase cleavage (Figures 3, 4A). These include stem-loops (Emory et al., 1992; McDowall et al., 1995; Arnold et al., 1998; Hambraeus et al., 2002), 5' UTRs and leader/leaderless status (Chen et al., 1991; Arnold et al., 1998; Unniraman et al., 2002; Nguyen et al., 2020), subcellular compartmentalization (Khemici et al., 2008; Montero Llopis et al., 2010; Murashko et al., 2012; Khemici et al., 2015; Moffitt et al., 2016), $5^{\prime}$ triphosphate groups (Bouvet and Belasco, 1992; Emory et al., 1992; Arnold et al., 1998; Mackie, 1998), $5^{\prime} \mathrm{NAD}^{+} / \mathrm{NADH} /$ dephospho-coenzyme A caps (Chen et al., 2009; Kowtoniuk et al., 2009; Bird et al., 2016; Frindert et al., 2018), $\mathrm{Np}_{\mathrm{n}} \mathrm{N}$ caps (Luciano et al., 2019; Hudecek et al., 2020), and association with regulatory proteins and sRNAs (Braun et al., 1998; Gualerzi et al., 2003; Moll et al., 2003; Afonyushkin et al., 2005; Daou-Chabo et al., 2009; Nielsen et al., 2010; Morita and Aiba, 2011; Faner and Feig, 2013; Liang and Deutscher, 2013; Deng et al., 2014; Sinha et al., 2018; Zhao et al., 2018; Cameron et al., 2019; Chen H. et al., 2019; Richards and Belasco, 2019). For example, in Streptococcus pyogenes the sRNA FasX binds to the $5^{\prime}$ end of ska - a transcript coding for streptokinase - increasing its mRNA half-life, thus allowing an extended period of time in which translation of streptokinase can occur (Ramirez-Pena et al., 2010). In other cases, the product of an mRNA can regulate its own transcript stability. In E. coli, the fate of the $l y s C$ transcript is regulated by a dual-acting riboswitch that, under low levels of lysine, promotes translation initiation while simultaneously sequestering RNase E cleavage sites. In the presence of lysine, the riboswitch folds into an alternative conformation that exposes RNase E cleavage motifs, in addition to blocking translation (Caron et al., 2012). In these examples, it is ultimately the conformational structure of the mRNA that allows regulation of its half-life, independently from the stability of the bulk mRNA pool.

The activity of RNases does not always result in RNA decay. Some mRNA precursors can be processed by RNases to create mature, functional forms of the transcript (Condon et al., 1996). In a similar manner, polycistronic transcripts can be cleaved by endonucleases to produce transcripts with varying degrees of stability; some examples include (Belasco et al., 1985; Baga et al., 1988; Nilsson and Uhlin, 1991; Nilsson et al., 1996; Ludwig et al., 2001; Esquerre et al., 2014; Xu et al., 2015). While this is a fascinating mechanism of gene-specific regulation, it is beyond the scope of this review. 
Environmental condition 1
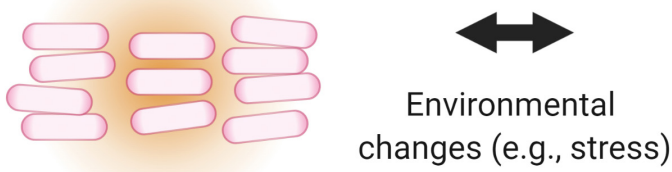

Environmental condition 2
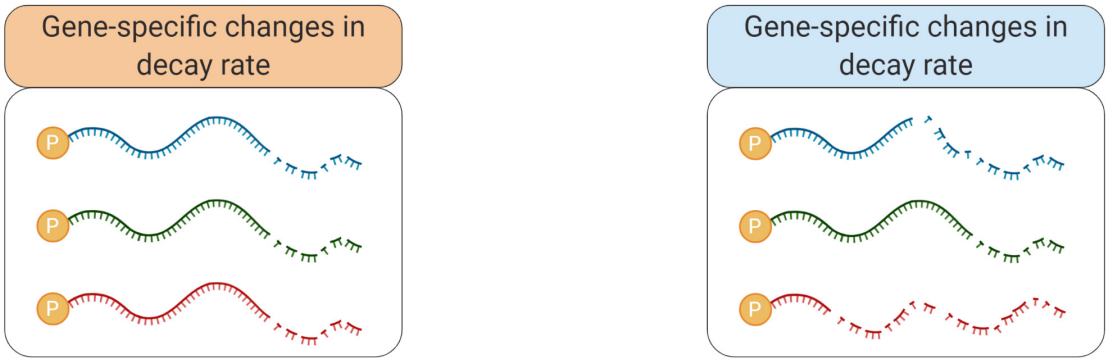

\section{Rapidly growing bacteria}

\section{Slowly growing bacteria}
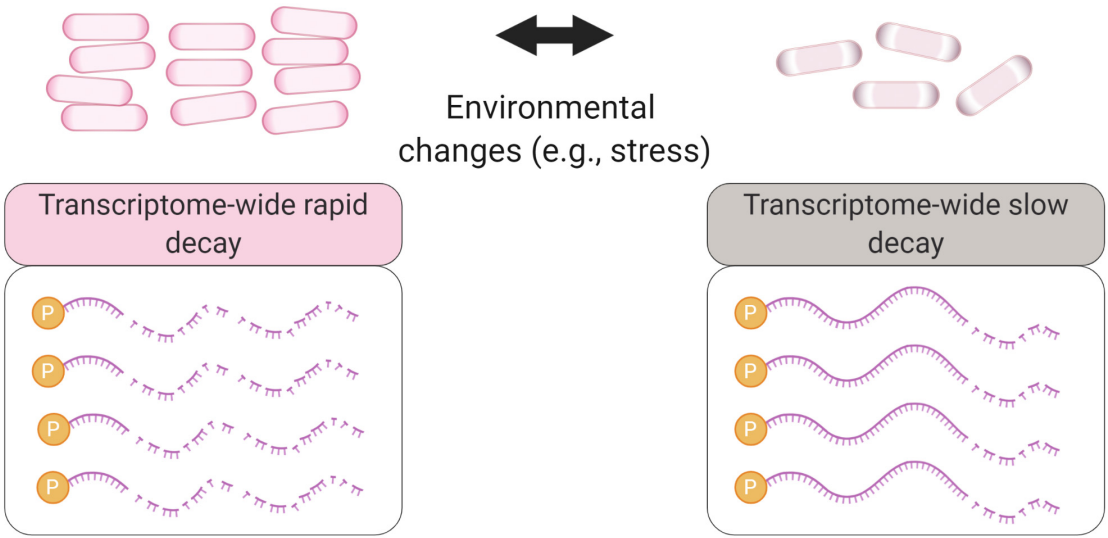

FIGURE 1 | Environmental changes cause mRNA degradation rates to change in both global and gene-specific ways. Bacterial adaptation to many stressors, and other changes in environment, involve modulation of degradation rates of specific transcripts encoding proteins relevant to the changing conditions (top panel). Some stressors, particularly those causing severe energy stress, trigger global stabilization of the mRNA pool (bottom panel). These scenarios are not mutually exclusive; stressors that cause global transcriptome stabilization typically also cause gene-specific changes in relative degradation rates.

\section{mRNA STABILIZATION AS A RESPONSE TO STRESS}

When bacteria are forced to slow or stop growth in response to stress, they must reduce their rates of protein synthesis. This can be done by direct modulation of translation or by regulation of transcription and transcript degradation rates. In recent decades, there have been many reports of mRNA stabilization as a response to different stressors, usually conditions that alter growth rate (see Table 1). In E. coli, the outer membrane protein A precursor transcript, ompA, is very stable in rapidly growing cells (Nilsson et al., 1984), but its half-life is significantly decreased in conditions of slow growth rate (Nilsson et al., 1984; Emory et al., 1992; Vytvytska et al., 2000). An inverse phenomenon was observed in stationary phase E. coli cells for
rpoS and $r m f$, transcripts coding for the transcription factor $\sigma 38$ and the ribosome modulation factor, respectively (Zgurskaya et al., 1997; Aiso et al., 2005). Research conducted in other organisms also showed regulation of degradation rates of specific mRNAs according to growth rate: $s d h$, coding for succinate dehydrogenase in B. subtilis, and rpoS in Salmonella dublin had mRNA half-lives negatively correlated with growth rate (Melin et al., 1989; Paesold and Krause, 1999). Furthermore, cell growth studies using chemostats revealed that most transcripts in E. coli stabilize at low growth rates (Esquerre et al., 2014), with those belonging to the COGs "Coenzyme transport and metabolism" and "Intracellular trafficking, secretion and vesicular transport" being enriched among the most highly stabilized transcripts. On the other hand, genes in "Cell motility" and "Secondary metabolites biosynthesis, transport and catabolism" had shorter 


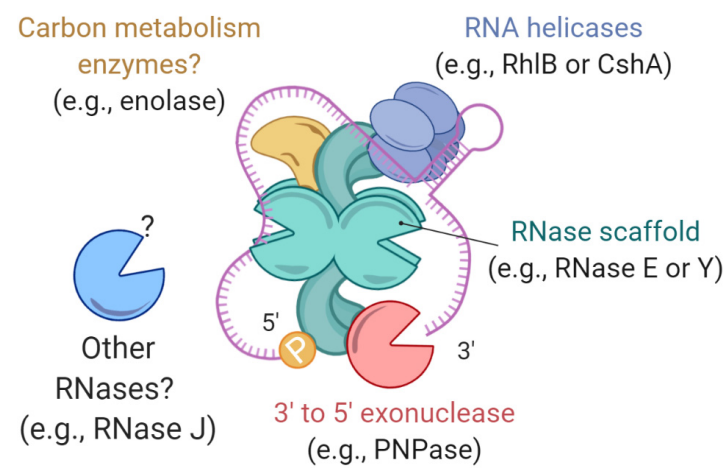

FIGURE 2 | Bacterial degradosomes. The bacterial degradosome is scaffolded by an RNase such as RNase E in E. coli and RNase $Y$ in B. subtilis. The RNase scaffolds have catalytic domains and natively disordered scaffold domains that bind other degradosome proteins. Typical degradosome components in both gram-positive and gram-negative bacteria are RNA helicases, carbon metabolism enzymes, and other RNases.

half-lives than the transcript population mean (Esquerre et al., 2015). This reinforces the ideas that transcript half-lives may be linked to gene function and can be regulated as conditions require. For example, in E. coli, genes from the COGs "Carbohydrate transport and metabolism" and "Nucleotide transport and metabolism" are amongst the most stable at normal growth rates (Esquerre et al., 2014, 2015, 2016). Although these findings propose a link between growth rate and mRNA stability, it is possible that metabolic status rather than growth rate per se is the key determinant of global mRNA stability. In $M$. smegmatis, a drug-induced increase in metabolic activity resulted in accelerated mRNA decay and vice versa, even though growth was halted in both conditions (Vargas-Blanco et al., 2019). Another study supported these findings, showing that mRNA stabilization upon changes in nutrient availability could be dissociated from changes in growth rate (Morin et al., 2020).

Growth rate is altered as a consequence of metabolic changes as bacteria adapt to different environments. Because the ultimate goal of an organism is to survive and multiply, we can assume that in stress conditions - such as low-nutrient environments bacteria trigger mechanisms that regulate energy usage and preserve energetically expensive macromolecules, such as mRNA. Thus, transcript stabilization is a logical response to various forms of energy stress. Indeed, E. coli stabilizes most of its transcriptome in anaerobic conditions (Georgellis et al., 1993) as well as in carbon starvation and stationary phase (Esquerre et al., 2014; Chen et al., 2015; Morin et al., 2020). Studies on Rhizobium leguminosarum, Vibrio sp. S14, and Lactococcus lactis also showed increased transcriptome half-lives when the bacteria are subjected to nutrient starvation (Albertson et al., 1990; Thorne and Williams, 1997; Redon et al., 2005a,b). S. aureus induces global mRNA stabilization in response to low and high temperatures, as well as during the stringent response (Anderson et al., 2006). Under hypoxic conditions, the median mRNA half-life in $M$. tuberculosis increases from $\sim 9.5 \mathrm{~min}$ to more than $30 \mathrm{~min}$, and cells shifted from $37^{\circ} \mathrm{C}$ to room temperature stabilized their transcriptomes so dramatically that half-lives could not be measured (Rustad et al., 2013). Similarly, transcript stabilization occurs in $M$. smegmatis in response to carbon starvation and hypoxia (Smeulders et al., 1999; VargasBlanco et al., 2019). Intriguingly, transcript destabilization can be resumed within seconds upon re-oxygenation of hypoxic M. smegmatis cultures, suggesting a highly sensitive mechanism regulating mRNA degradation in response to stress and energy status (Vargas-Blanco et al., 2019).

This response seems to be conserved even in some eukaryotes such as Saccharomyces cerevisiae, where the mRNA turnover rate is slower under stress than in log phase (Jona et al., 2000), and in plants as part of their immune response ( $\mathrm{Yu}$ et al., 2019). However, the adaptive mechanism(s) underlying global mRNA stabilization as a stress response remain unknown. In the following sections we will discuss in more detail diverse bacterial strategies that contribute to global and gene-specific regulation of RNA stability. Our intent is to highlight recent findings on regulation of RNA degradation, to serve as a base for development of experiments to uncover how mRNA stabilization occurs as a response to stress.

\section{Regulation of RNA Degradation Proteins}

In this section we will discuss factors that have been shown to regulate the abundance and activity of endo- and exonucleases. We invite the reader to consult some excellent reviews (Condon, 2003; Arraiano et al., 2010; Bechhofer and Deutscher, 2019) for additional information on the roles and activities of RNases.

As we described in a previous section, RNases have preferred cleavage sequences. These patterns can be either masked or exposed by alternative RNA folding configurations as a result of intracellular changes, allowing modulation of specific cleavage events, e.g., the lys $C$ riboswitch which is sensitive to lysine concentration (Caron et al., 2012). However, this regulatory paradigm tends to be used to control specific messages rather than the overall transcriptome stability. Hence, a major open question is: Are there elements that control RNase abundance or RNase activity that regulate transcriptome stability globally?

Abundance of key RNases that catalyze rate-limiting steps in mRNA degradation can affect bulk mRNA decay. For example, depletion or mutation of RNase E caused bulk mRNA stabilization in E. coli (Lopez et al., 1999; Sousa et al., 2001); depletion or mutation of RNase Y caused bulk mRNA stabilization in B. subtilis and S. pyogenes (Shahbabian et al., 2009; Chen et al., 2013); depletion of RNase J caused bulk mRNA stabilization in Helicobacter pylori (Redko et al., 2016); and deletion of RNases J1 and J2 caused mRNA stabilization in B. subtilis (Even et al., 2005). Mechanisms for regulation of RNase abundance have been reported in some bacteria. In E. coli, RNase III autoregulates its abundance by cleaving its own operon to induce its degradation when RNase III protein levels are high (Bardwell et al., 1989; Matsunaga et al., 1996, 1997; Xu et al., 2008). Similarly, in E. coli a stem-loop located in the $5^{\prime}$ UTR of rne responds to changes in RNase E levels, allowing this enzyme to autoregulate its own production (Diwa et al., 2000; Diwa and Belasco, 2002). There is evidence that in some cases, stability of other mRNAs can be regulated by changes in RNase 
A

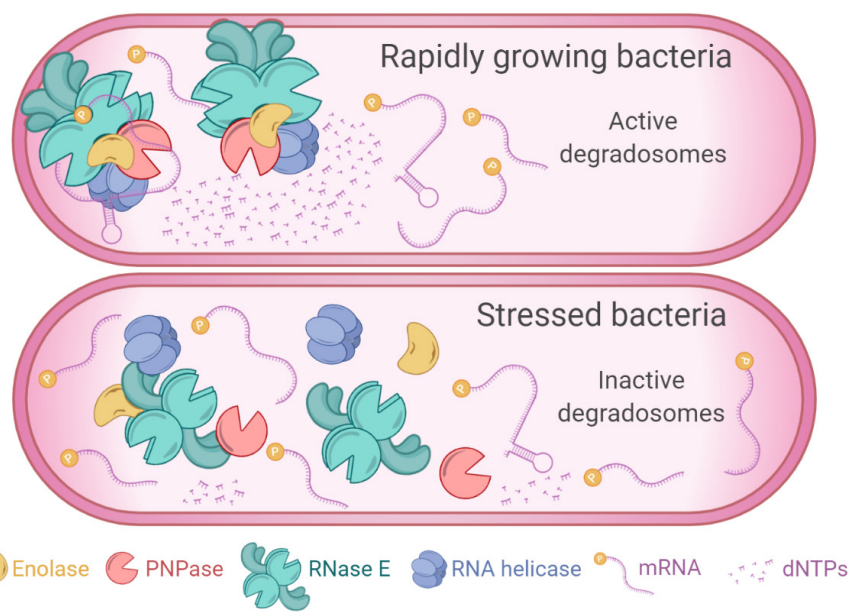

C $\quad 5^{\prime}$ triphosphate cap

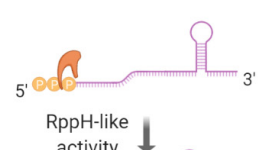

RppH-like
activity

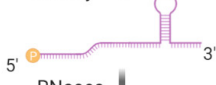

RNases $\downarrow$

$+\pi+\pi+\pi+4$

mRNA modifications

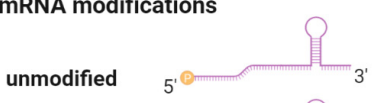

m6A
5 ' non-canonical caps

(increased abundance under certain stresses)

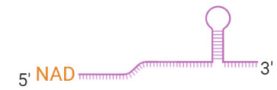

5. NAD mmmntm

NudC/
BsRppH

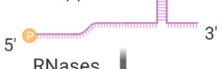

RNases $\downarrow$

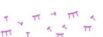

$\pi+\pi+\pi \pi^{2}+$
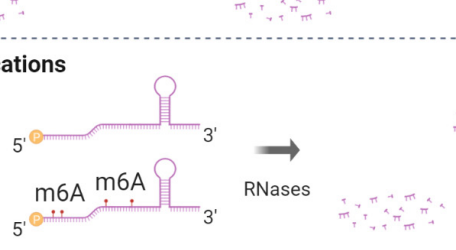

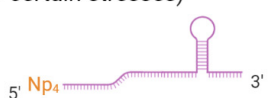

$\mathrm{RppH}+\mathrm{ApaH} /$

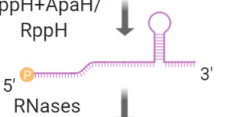

RNases

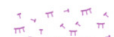

B

Constitutive or stress-responsive RNA

binding proteins (RBP)

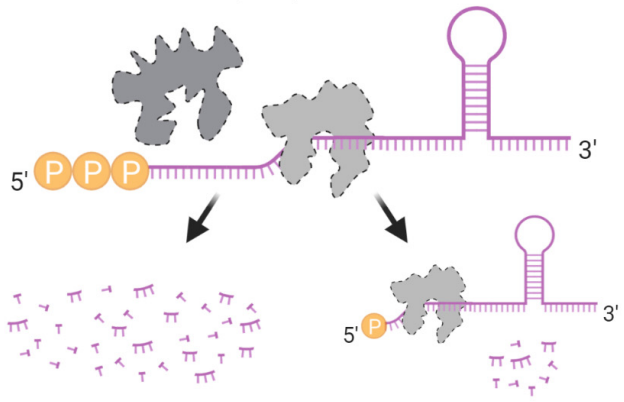

Faster degradation or Slower degradation

(RBP and mRNA specific)

D
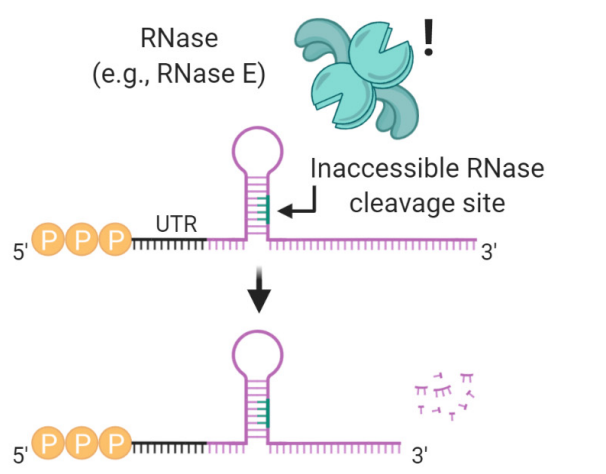

Slower degradation

(mRNA specific)

FIGURE 3 | Common mechanisms that can protect mRNAs from degradation. (A) Degradosome localization can influence its RNA degradation activity. In E. coli, the degradosome is anchored to the cytoplasmic membrane via RNase E's N-terminal domain, where it displays higher RNA processing activity in degradation foci. A cytoplasmic RNase $E$ is less efficient in degradosome assembly and RNA processing. In $B$. subtilis, RNase $Y$ is associated with the membrane and is more active when in smaller foci and less active when in larger foci. (B) RNA binding proteins can modulate mRNA degradation. Some of them, such as CsrA in $\gamma$-Proteobacteria, have regulatory roles as a response to environmental changes. (C) The chemical nature of mRNA $5^{\prime}$ ends can protect transcripts from degradation. These caps may vary depending on stress conditions. Nucleotide modifications in the bodies of transcripts have also been reported, but they have not been shown to alter mRNA stability. (D) RNA degradation depends on RNase accessibility to cleavage sites. Secondary structures that block cleavage sites can result in slower RNA degradation.

abundance. In $E$. coli, the bet $T$ and proP transcripts, encoding osmoregulators, showed increased abundance and stability when cells were subject to osmotic stress, apparently as a consequence of lower RNase III concentrations (Sim et al., 2014). However, there is not yet evidence that global stress-induced mRNA stabilization can be attributed to reduced RNase abundance. In M. tuberculosis, a quantitative proteomics study comparing exponentially growing and hypoxic cultures showed no alteration in levels of RNase E, RNase J, RNase III, PNPase, or the helicase HelY even after 20 days under hypoxia (Schubert et al., 2015). Only one RNA helicase, RhlE, had reduced levels in hypoxia (Schubert et al., 2015). Similarly, a study of M. smegmatis showed no variation in levels of RNase E, PNPase, or the predicted RNA helicase msmeg_1930 under hypoxia, re-aeration, or exponential growth (Vargas-Blanco et al., 2019). Because mycobacterial transcriptomes are rapidly stabilized upon encountering hypoxia and other stress conditions (Rustad et al., 2013; Vargas-Blanco et al., 2019), it is unlikely that alteration of RNase abundance is part of the early RNA stabilization responses in these organisms.

It is possible that the activity of existing RNA degradation enzymes is regulated. RNA helicases are ATP-dependent, and ATP levels decrease in some bacteria in severe energy stress (Rao et al., 2008; Vargas-Blanco et al., 2019). This raises the possibility that RNA degradation could be directly modulated by ATP levels. However, when this hypothesis was tested in M. smegmatis, mRNA stabilization was found to occur prior to a decrease in intracellular ATP levels upon exposure to hypoxic conditions (Vargas-Blanco et al., 2019). While these findings suggest that nucleotide sensing - particularly changes in ATP concentrations - does not influence the initial global stabilization response in mycobacteria, it is possible that ATP concentrations or ATP/ADP ratios could be responsible for further stabilization 

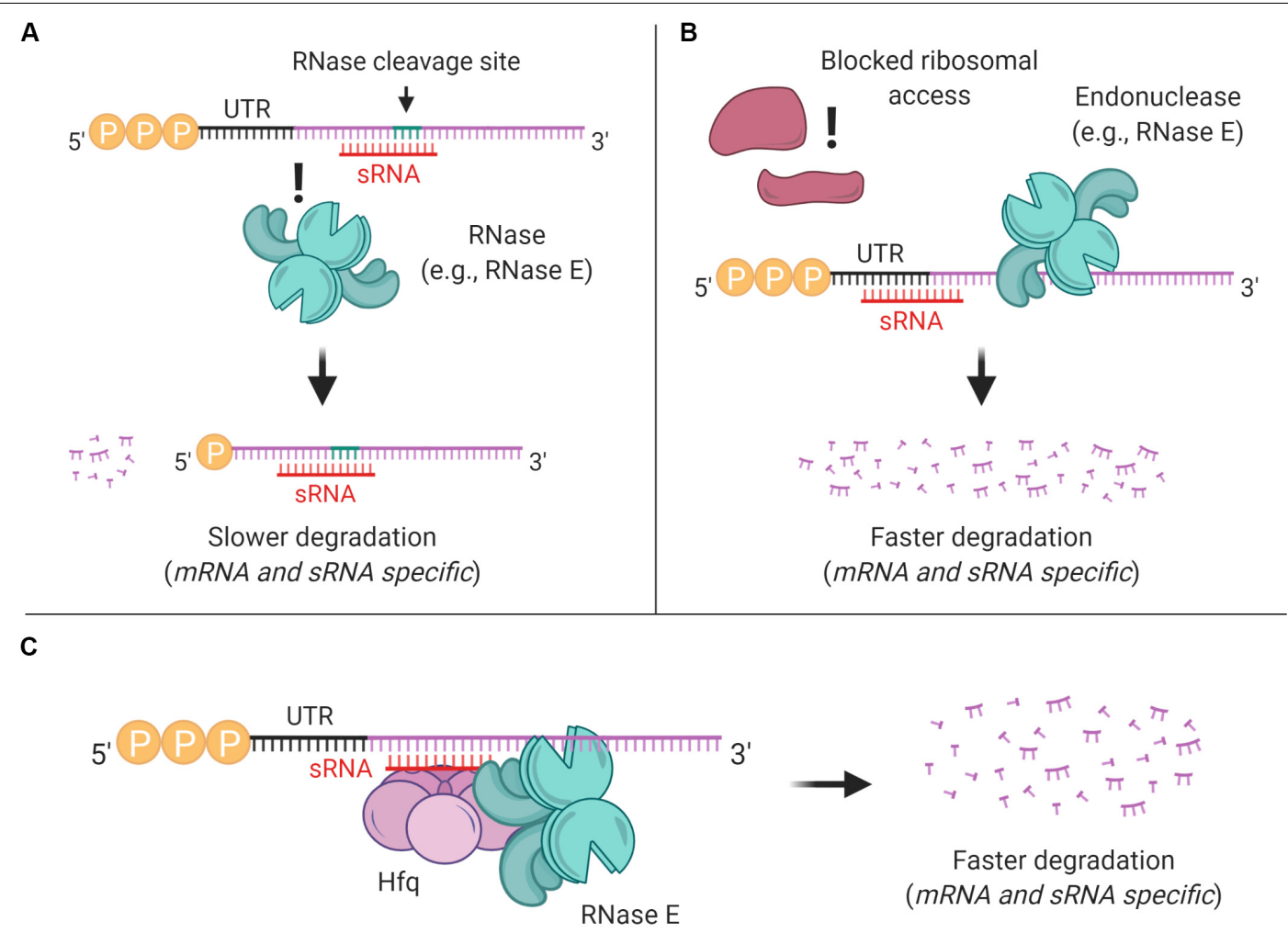

FIGURE 4 | sRNAs can affect mRNA stability through multiple mechanisms. (A) sRNA binding can mask preferred RNase cleavage sites, thereby stabilizing transcripts. (B) sRNA binding can block ribosome access to Shine-Dalgarno sites, reducing translation and typically destabilizing transcripts. (C) In E. coli and some other gram-negative bacteria, sRNA-mRNA pairing is often mediated by Hfq, which typically leads to mRNA degradation.

in later stages of dormancy, and/or that ATP levels contribute to global mRNA stabilization in other bacteria. The roles of nucleotides associated with the stringent response are discussed separately below.

In E. coli, inhibition of RNase E activity by RraA and RraB (Regulator of ribonuclease activity $\mathrm{A}$ and $\mathrm{B}$ ) result in increased bulk mRNA half-life (Lee et al., 2003). However, in the case of RraA, the effect was observed after a significant overexpression of the inhibitor (Lee et al., 2003), something not observed under stress. Alternatively, inhibition of RNase activity by other factors may regulate transcript degradation. RNase E was recently shown to have a $5^{\prime}$ linear scanning function, and its cleavage activity is impaired upon encountering obstacles, such as sRNAs or ribosomes (Richards and Belasco, 2019). Furthermore, in E. coli, the activity of RNase E has been shown to depend on its anchorage to the inner membrane (Figure 3A). YFP-tagged RNase E forms small foci localized at the inner membrane (Strahl et al., 2015) which are dependent on metabolic activity; in anaerobic conditions RNase E rapidly dissociates from the membrane and diffuses in the cytoplasm, a response apparently dependent on enolase (Murashko and Lin-Chao, 2017). A cytoplasmic version of RNase E was unstable, and led to increased mRNA half-lives (Hadjeras et al., 2019). Interestingly, the cytoplasmic RNase E was able to assemble a degradosome and had a comparable in vitro activity to wild type RNase E, supporting the role of membrane attachment and cellular localization in RNase E activity (Moffitt et al., 2016; Hadjeras et al., 2019). Conversely, in Caulobacter crescentus, RNase E is cytoplasmic and forms bacterial ribonucleoprotein (BR) bodies, which dynamically assemble and disassemble in the presence of mRNA (Al-Husini et al., 2018). BR body formation was dependent on the RNase E scaffold domains and the presence of mRNA, while disassembly of the bodies required mRNA cleavage (Al-Husini et al., 2018). Intriguingly, the formation of BR-bodies increased under some stress conditions but was unaffected by others, suggesting they play an as-yet undefined role in stress response (Al-Husini et al., 2018). Further work is needed to understand the extent to which RNase localization contributes to regulation of mRNA degradation rates in various species.

In B. subtilis, the activity of RNase Y appears to be regulated by both subcellular localization and association with proteins termed the Y-complex (YaaT, YlbF, and YmcA). The Y-complex affects expression of genes involved in biofilm formation, sporulation, and competence, and in some cases, this was shown to be a direct consequence of altered mRNA degradation rates for the relevant genes (Tortosa et al., 2000; Carabetta et al., 2013; DeLoughery et al., 2016; Dubnau et al., 2016). The Y complex has been viewed as a specificity factor for RNase Y, required in particular for processing of polycistronic transcripts (DeLoughery et al., 2018). RNase Y also localizes in the cell membrane, where it can form RNase Y foci (Hunt et al., 2006; Lehnik-Habrink et al., 2011; Hamouche et al., 2020). These foci 
seem to represent a less active form of the enzyme, as they increased in size in absence of RNA or in Y-complex mutants (Hamouche et al., 2020).

\section{The Stringent Response and mRNA Degradation}

The stringent response is perhaps one of the most wellstudied mechanisms of prokaryotic stress adaptation. This response is modulated by guanosine- $3^{\prime}, 5^{\prime}$-bisphosphate (ppGpp)

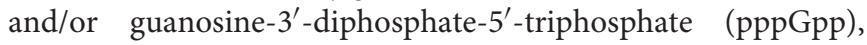
alarmones collectively referred to as (p)ppGpp. In gram-negative bacteria, (p)ppGpp is synthesized by RelA in response to uncharged-tRNAs binding ribosomes, or by SpoT, a (p)ppGpp synthase/hydrolase, during fatty acid starvation (Seyfzadeh et al., 1993; Battesti and Bouveret, 2009). In some gram-positive bacteria, (p)ppGpp is synthesized by a dual RelA/SpoT homolog (Atkinson et al., 2011; Frederix and Downie, 2011; Corrigan et al., 2016). Once produced, (p)ppGpp halts the synthesis of stable RNA (tRNAs and ribosomes) while upregulating stress-associated genes and downregulating those associated with cell growth (Gentry et al., 1993; Chakraburtty and Bibb, 1997; Martinez-Costa et al., 1998; Avarbock et al., 2000; Artsimovitch et al., 2004; Corrigan et al., 2016). Intriguingly, (p)ppGpp was reported to inhibit PNPase in the actinomycetes Nonomuraea sp. and Streptomyces coelicolor but not in E. coli (Gatewood and Jones, 2010; Siculella et al., 2010), suggesting the stringent response may have a previously overlooked role in directly regulating mRNA degradation in some groups of bacteria. However, a recent study on the stringent response in $M$. smegmatis showed that (p)ppGpp was not required for mRNA stabilization in response to carbon starvation or hypoxia (Vargas-Blanco et al., 2019).

In the pathogen Borrelia burgdorferi, a connection between the stringent response and the expression of 241 sRNAs was recently stablished, 187 of which were upregulated during nutrient stress (Drecktrah et al., 2018). The authors of the aforementioned study described potential mechanisms of regulation by $\operatorname{Re}_{\mathrm{Bbu}}$ on transcription and fate of some transcripts, such as destabilization of the glycerol uptake facilitator transcript, $g l p F$. The SR0546 sRNA is among the sRNAs induced by nutrient starvation; the upregulation of its target, bos $R$, encoding a transcriptional regulator, may suggest a regulatory role of (p)ppGpp on specific mRNA stabilization. However, the effects of these stringent response-induced sRNAs on mRNA stability have not yet been directly tested.

A surprising role of RelZ (initially called MS_RHII-RSD), a dual (p)ppGpp synthase and RNase HII, was reported for M. smegmatis (Murdeshwar and Chatterji, 2012). R-loops (RNA/DNA hybrids) are harmful structures that cause replication stress and can be removed by the RNase $\mathrm{H}$ domain of RelZ, while stalled ribosome removal is attributed to their alarmone synthase domain. RelZ was shown to be upregulated under short UV exposure in M. smegmatis (Krishnan et al., 2016), and while its role is suspected to increase cell viability under stress conditions (Petchiappan et al., 2020), the stringent response seems to not intervene in transcriptome stability regulation. This pathway leads to degradation of transcripts involved in R-loops, but given the low frequency of R-loop formation, the effects on mRNA pools are likely to be minimal.

Overall, there is much evidence that the stringent response regulates expression of specific transcripts in various bacteria. However, the extent to which control of mRNA stability contributes to these effects is mostly untested. The stringent response also plays important roles in mediating global responses to starvation and other forms of energy stress, but there is not yet evidence that it contributes to global mRNA stabilization, which is a consistent component of these stress responses. This suggests that the stringent response may not be the mediator of global mRNA stabilization in response to stress, or that its involvement in this process is species-specific.

\section{Transcript Modifications as Regulators of mRNA Decay}

Bacterial mRNA is primarily transcribed using nucleoside triphosphates as initiating nucleotides, making mRNAs triphosphorylated at their $5^{\prime}$ ends. In S. aureus, RNase J1 exhibits strong in vitro exo- and endonucleolytic activities on $5^{\prime}$ triphosphorylated transcripts (Hausmann et al., 2017). However, in most other organisms studied to date, RNases E, J, and $\mathrm{Y}$ more efficiently cleave mRNAs with $5^{\prime}$ monophosphates (Figure 3C). RNase E is an endoribonuclease, but has a binding pocket for monophosphorylated $5^{\prime}$ ends (Callaghan et al., 2005) that strongly stimulates its activity in organisms including E. coli and M. tuberculosis (Mackie, 1998; Zeller et al., 2007). Similarly, in B. subtilis, RNase J1, and to a lesser extent J2, show a strong preference toward $5^{\prime}$ monophosphorylated substrates (Even et al., 2005). RNase Y also shows preference toward monophosphorylated $5^{\prime}$ substrates, but to a lesser extent (Shahbabian et al., 2009). These findings contributed to the discovery of $\mathrm{RppH}$, an RNA pyrophosphohydrolase. Similar enzymes were later found in other bacteria, such as Bdellovibrio bacteriovorus (Messing et al., 2009) and B. subtilis (Richards et al., 2011). However, while the role of $5^{\prime}$ triphosphate pyrophosphohydrolysis was initially attributed to $\mathrm{RppH}$ (Celesnik et al., 2007; Deana et al., 2008), recent findings have shown that the primary substrate of $\mathrm{RppH}$ in E. coli is $5^{\prime}$ diphosphorylated RNAs, and that $5^{\prime}$ diphosphorylated RNAs are abundant in the transcriptome (Luciano et al., 2017). As $\mathrm{RppH}$ cannot convert $5^{\prime}$ triphosphates to diphosphates, this suggests the existence of an unknown $5^{\prime}$ triphosphate to diphosphate phosphorylase. Given that $5^{\prime}$ monophosphates make transcripts more susceptible to degradation in multiple organisms, one could envision regulation of $5^{\prime}$ triphosphate pyrophosphohydrolysis as a potential mechanism for regulation of mRNA stability. However, to our knowledge there are not yet reports of if and how pyrophosphohydrolysis or $\gamma$-phosphate removal are regulated.

The presence of non-canonical mRNA $5^{\prime}$ ends has recently been reported for subsets of mRNAs in several bacterial species, suggesting another possible mechanism for regulation of mRNA stability (Figure 3C). Examples include NADH and NAD+ (Chen et al., 2009; Cahova et al., 2015), and less commonly, dephospho-CoA, succinyl-CoA, acetyl-CoA, and 
methylmalonyl-CoA (Kowtoniuk et al., 2009). We will refer to these as $5^{\prime}$ caps, with the understanding that they are structurally and functionally distinct from eukaryotic mRNA caps. Other studies have shown additional types of $5^{\prime}$ capping, as well as potential mechanisms behind it (Bird et al., 2016; Zhang et al., 2016; Julius and Yuzenkova, 2017). In most cases, bacterial caps are incorporated directly into mRNAs during transcription initiation. RNA polymerase can initiate transcription with noncanonical nucleotides such as NAD in E. coli (Bird et al., 2016; Vvedenskaya et al., 2018) and B. subtilis (Frindert et al., 2018). Furthermore, E. coli RNA polymerase seems to initiate with dinucleoside tetraphosphates $\left(\mathrm{Np}_{4} \mathrm{~N}\right), \mathrm{Np}_{4} \mathrm{~A}$ in particular, with an efficiency almost 60 times higher than for NAD (Luciano and Belasco, 2020). Alternative, posttranscriptional mechanisms may also contribute to $\mathrm{Np}_{4}$ capping formation, as in vitro experiments using LysU (lysyl-tRNA synthetase) from E. coli suggest (Luciano et al., 2019).

The intracellular concentration of $\mathrm{Np}_{4} \mathrm{As}$ were shown to be affected by overproduction of aminoacyl-tRNA synthetases (Brevet et al., 1989). Interestingly, some stress conditions also induce higher levels of $\mathrm{Np}_{4} \mathrm{Ns}$, for example heat shock (Lee et al., 1983), oxidative stress (Bochner et al., 1984), cadmium stress (Coste et al., 1987; Luciano et al., 2019) and disulfide stress (Bochner et al., 1984; Luciano et al., 2019). $5^{\prime}$ mRNA decapping was shown to require Nudix enzymes, such as NudC and BsRppH, to hydrolyze NAD-RNA substrates (Hofer et al., 2016; Frindert et al., 2018). On the other hand, hydrolysis of $\mathrm{Np}_{4}$ As requires $\mathrm{RppH}$ and $\mathrm{ApaH}$, the latter carrying out the hydrolysis of $\mathrm{Np}_{4} \mathrm{As}$ into two NDPs (Farr et al., 1989); in this context ApaH generates a diphosphorylated $5^{\prime}$ end that can be readily converted to monophosphate $5^{\prime}$ end by $\mathrm{RppH}$ (Figure 3C). Noncanonical mRNA $5^{\prime}$ ends also occur when transcription initiates with short RNA degradation products, resulting in mRNAs with $5^{\prime}$ hydroxyls (Druzhinin et al., 2015). Such transcripts have been found in E. coli and Vibrio cholerae and are present at increased abundance in stationary phase (Vvedenskaya et al., 2012; Druzhinin et al., 2015). However, the effects of these alternate $5^{\prime}$ ends on transcript stability have not been reported.

Some mRNA caps have been shown to stabilize mRNAs in E. coli (Bird et al., 2016; Luciano et al., 2019) and in B. subtilis (Frindert et al., 2018). For example, after increasing the cellular concentration of $\mathrm{Np}_{4} \mathrm{Ns}$ in cadmium-stressed cells and in $\triangle a p a H$ mutants, RNA stability was increased, suggesting that $\mathrm{Np}_{4}$ caps have a stabilizing role (Luciano et al., 2019). Additionally, in this study $\mathrm{Np}_{4}$ caps were suggested to be more abundant than NAD caps. Similarly, in the E. coli $\triangle$ nudC mutant strain there is an increase of up to fourfold in RNA stability for transcripts with non-canonical $5^{\prime}$ caps (Bird et al., 2016). Furthermore, NAD $5^{\prime}$ caps were almost twofold more abundant for cells in stationary phase when compared to exponential phase (Bird et al., 2016). Together, these findings present a potential mechanism for stabilization of mRNA under stress conditions. An interesting regulatory mechanism behind $\mathrm{Np}_{4}$ decapping in E. coli was recently linked to methylation in $\mathrm{m}^{7} \mathrm{Gp}_{4} \mathrm{Gm}$ and $\mathrm{m}^{6} \mathrm{Ap}_{3} \mathrm{~A} 5^{\prime}$ caps, which protects them from $\mathrm{RppH}$ cleavage but not from AppH (Hudecek et al., 2020). Methylated $\mathrm{Np}_{n} \mathrm{~N}$ caps were shown to be more abundant in stationary phase than exponential phase (Hudecek et al., 2020), consistent with the idea that these caps protect mRNA from degradation. Interestingly, the $\mathrm{Np}_{\mathrm{n}} \mathrm{N}$ caps found in that study did not include $\mathrm{Ap}_{4} \mathrm{~N}$ (Hudecek et al., 2020), presumably due to different stress conditions and detection techniques than those in Luciano et al. (2019). Since capped mRNAs appear to be generally more stable than canonical mRNAs, it is logical to infer that when stress conditions cause growth to slow or stop and transcription to slow or stop concomitantly, the proportion of capped mRNAs will increase as a result of their inherently longer half-lives. One could therefore speculate that the global mRNA stabilization observed in non-growing bacteria is due in part to an mRNA pool that is largely protected by $5^{\prime}$ caps. This is plausible assuming capping frequency remains constant or increases under stress. But, a recent study argues against this idea. Rapid transcript destabilization occurred in hypoxic $M$. smegmatis cultures after re-exposure to oxygen, even when transcription was blocked prior to re-aeration (Vargas-Blanco et al., 2019). Thus, mRNA capping does not explain the transcript stabilization observed in these conditions (early-stage hypoxia) - at least in M. smegmatis but could be involved in mRNA stabilization in other conditions and/or other bacteria.

Another possible mechanism of mRNA stabilization involves posttranscriptional nucleotide modifications (Figure 3C). $N^{6}$ methyladenosine $\left(\mathrm{m}^{6} \mathrm{~A}\right)$ is a common base modification in mice and humans (Meyer et al., 2012; Linder et al., 2015). This methylation is enriched near stop codons and in 3' UTRs (Yue et al., 2018), and is dependent on the consensus motif DRACH (Linder et al., 2015). Recent studies revealed $\mathrm{m}^{6} \mathrm{~A}$ to be an important part of a transcript stability regulatory mechanism, as it facilitates mRNA degradation in association with RBP in mice, zebra fish, and human cells (Schwartz et al., 2014; Wang et al., 2014; Zhao et al., 2017). Moreover, the levels of $\mathrm{m}^{6} \mathrm{~A}$ methylation are responsive to stress conditions, as shown for human cancer cells under hypoxic conditions (Panneerdoss et al., 2018), suggesting a posttranscriptional regulatory role. In E. coli and Pseudomonas aeruginosa, $\mathrm{m}^{6} \mathrm{~A}$ is present at similar levels, $\sim 0.2-0.3 \%$ of adenines (Deng W. et al., 2015), to those reported for yeast and other eukaryotes (Wei et al., 1975; Bodi et al., 2010). However, in contrast to mammals, $\mathrm{m}^{6} \mathrm{~A}$ appears distributed throughout the gene, with modest enrichments near the $5^{\prime}$ ends and centers of transcripts, and with a similar $\mathrm{m}^{6} \mathrm{~A}$ motif for $E$. coli and $P$. aeruginosa (UGCCAG and GGYCAG, respectively) (Deng $X$. et al., 2015). Contrary to eukaryotes, $\mathrm{m}^{6} \mathrm{~A}$ methylation has not been shown to have a global role in mRNA degradation in bacterial stress responses. A deep analysis in $E$. coli and $P$. aeruginosa revealed no difference in the $\mathrm{m}^{6} \mathrm{~A}$ levels for cells growing in LB when compared to other (unspecified) growth media, or oxidative stress; interestingly, increasing the temperature from 37 to $45^{\circ} \mathrm{C}$ lowered $\mathrm{m}^{6} \mathrm{~A}$ methylation levels, but only for P. aeruginosa (Deng X. et al., 2015). Furthermore, the $\mathrm{m}^{6} \mathrm{~A}$ levels were lower in other bacteria $(\sim 0.02-0.08 \%$, for S. aureus, B. subtilis, Anabaena sp., and Synechocystis sp.) (Deng X. et al., 2015), suggesting that this particular base modification may not be conserved across bacteria. In E. coli, codon modifications of the ermCL mRNA with $\mathrm{m}^{6} \mathrm{~A}$ blocked translation, though it had no impact on mRNA degradation rates 
(Hoernes et al., 2016). While it is conceivable that $\mathrm{m}^{6} \mathrm{~A}$ has a role in the regulation of bacterial translation, current evidence does not suggest it regulates $\mathrm{mRNA}$ fate.

5-methylcytosine $\left(\mathrm{m}^{5} \mathrm{C}\right)$ has also been found in mRNA. In eukaryotes, $\mathrm{m}^{5} \mathrm{C}$ has been shown to increase transcript stability (Arango et al., 2018; Chen X. et al., 2019; Yang et al., 2019; Schumann et al., 2020), while reports on translation regulation are controversial (Huang et al., 2019; Yang et al., 2019; Schumann et al., 2020). $\mathrm{m}^{5} \mathrm{C}$ modifications have been found in mRNA and $23 \mathrm{~S}$ rRNA in the archaeon Solfolobus solfataricus (Edelheit et al., 2013). However, there is no defined role of $\mathrm{m}^{5} \mathrm{C}$ in $\mathrm{S}$. solfataricus, and evidence of $\mathrm{m}^{5} \mathrm{C}$ in bacteria or regulatory roles in RNA degradation have not been reported.

Another modification, and perhaps the most abundant in RNA, is pseudouridine ( $\Psi$ ) (Rozenski et al., 1999). $\Psi$ is present at the position U55 in all E. coli tRNAs (Gutgsell et al., 2000), and is widespread across kingdoms (Nishikura and De Robertis, 1981; Becker et al., 1997; Ishida et al., 2011). In E. coli, deletion of truB, encoding a tRNA $\Psi 55$ synthase (Nurse et al., 1995), was shown reduce viability after a temperature shock $\left(37-50^{\circ} \mathrm{C}\right)$; however, no viability changes were observed during exponential growth at $37^{\circ} \mathrm{C}$ (Kinghorn et al., 2002). In Thermus thermophilus, a $\triangle \operatorname{tru} B$ mutant showed a growth defect when cultured at $50^{\circ} \mathrm{C}$ (Ishida et al., 2011). Thus, it is possible that the presence of tRNA modifications under stress conditions contributes to survival in other bacteria. Other tRNA modifications have been also reported in bacteria and yeast during stress, contributing to a translational bias with implications for translation regulation (Chan et al., 2010, 2012; Laxman et al., 2013; Deng W. et al., 2015; Chionh et al., 2016). However, while stress may alter tRNA modifications, ultimately these changes lead to translational regulation without clear evidence, at least in bacteria, of effects on mRNAs. On the other hand, $\Psi$ modifications on mRNA have been shown to increase mRNA stability in yeast and human cells (Carlile et al., 2014) and in Toxoplasma gondii (Nakamoto et al., 2017). A broad study involving E. coli and human cells found that even a single replacement of $U$ with $\Psi$ in mRNA can interfere with translation (Eyler et al., 2019). Whether these modifications ultimately regulate mRNA stability in bacteria as a response to stress is an open question. Based on evidence aforementioned for M. smegmatis regarding the rapidity of transcript destabilization after stress alleviation (VargasBlanco et al., 2019), we speculate that base modifications are unlikely to be the primary mechanism of mRNA stabilization in hypoxic mycobacteria, although it could play roles in other organisms or conditions.

\section{Roles of Ribosomes, Translation, sRNAs, and RNA-Binding Proteins in Regulation of mRNA Decay}

Experiments conducted by Bechhofer and others in B. subtilis showed that ribosome stalling can increase erm $C$ half-life. In this scenario, ribosomes acted as obstacles at the $5^{\prime}$ ends of transcripts, resulting in protection from endonucleolytic cleavage downstream (Shivakumar et al., 1980; Bechhofer and Dubnau, 1987; Bechhofer and Zen, 1989). These findings would become early evidence of a $5^{\prime}-3^{\prime}$ polarity for endonucleolytic activity, dependent upon or enhanced by (1) interaction with a $5^{\prime}$ monophosphate, and (2) RNase linear scanning mechanisms, as it would be later reported by others (Bouvet and Belasco, 1992; Jourdan and McDowall, 2008; Kime et al., 2010; Richards and Belasco, 2016, 2019). In E. coli, the use of puromycin or kasugamycin - translation inhibitors that cause ribosomes to dissociate from transcripts - caused faster mRNA decay in the absence of new transcription (Varmus et al., 1971; Pato et al., 1973; Schneider et al., 1978). On the other hand, the use of chloramphenicol, fusidic acid or tetracycline - elongation inhibitors that cause ribosomes to stall on transcripts - resulted in transcript stabilization (Varmus et al., 1971; Fry et al., 1972; Pato et al., 1973; Schneider et al., 1978), findings also later shown in M. smegmatis (Vargas-Blanco et al., 2019). These results are consistent with ribosome binding having a protective effect on mRNAs (Figure 5). In experiments where transcription was not blocked, it is possible that the mRNA stabilization seen in response to elongation inhibitors may also be conferred in part by the sudden increase in rRNA synthesis that these drugs cause, which increases the abundance of potential RNase substrates and could therefore titrate the activity of RNases such as PNPase and RNase E (Lopez et al., 1998). However, the increase in rRNA synthesis cannot fully explain these effects.

In $B$. subtilis, the stability of $g s i B$, encoding general stress protein, and erm $C$, encoding erythromycin resistance leader peptide, are associated with ribosome binding (Sandler and Weisblum, 1989; Hambraeus et al., 2000). Mutations to the RBS sites of $g s i B$, aprE (coding for subtilisin), and SP82 phage mRNA resulted in reductions of their mRNA half-lives (Hue et al., 1995; Jurgen et al., 1998; Hambraeus et al., 2002). Transcript stability conferred by ribosomes does not always require productive translation, at least for ermC (Hambraeus et al., 2002) and ompA (Emory and Belasco, 1990), where transcripts were stable in the absence of start codons as long as strong Shine-Dalgarno (SD) sequences were present (Arnold et al., 1998). A later study also in E. coli reported that ribosome protection is independent of translation for another transcript (Wagner et al., 1994). Transcript stabilization in a translation-independent manner was also shown for B. subtilis, with the insertion of an alternative SD (not involved in translation) to the gene reporter cryIII (Agaisse and Lereclus, 1996). These findings suggest that binding of a $30 \mathrm{~S}$ subunit to a transcript, regardless of translation, may suffice to impair RNase degradation.

However, other studies did find a correlation between translation itself and stability. In E. coli, codon composition can influence translation rate and mRNA stability; codon-optimized transcripts were more stable than their corresponding nonmodified, inefficiently-translated versions (Boel et al., 2016). Similar results were shown for S. cerevisiae (Presnyak et al., 2015). A transcriptome-wide analysis in E. coli also identified a positive correlation between mRNA stability and codon content optimality, for bacteria growing at different rates (Esquerre et al., 2015). This directly contradicted a previous report that codon optimality and half-life were inversely correlated (Lenz et al., 2011), possibly due to use of different codon optimality metrics. In B. subtilis, translation initiation is necessary to prevent 


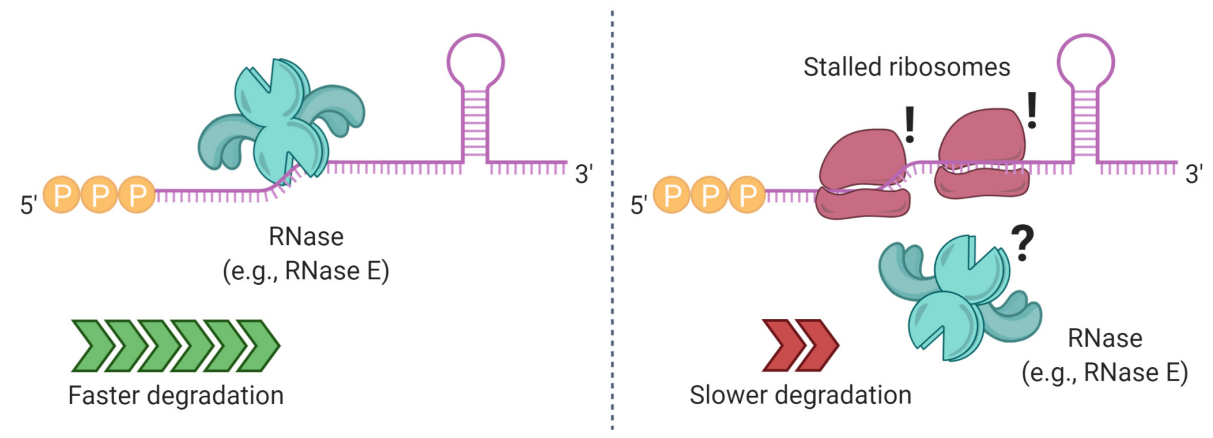

FIGURE 5 | Ribosome binding and stalling can alter mRNA degradation. In some cases, ribosome stalling can mask RNase cleavage sites, increasing the half-life of a transcript. Elements that prevent ribosome binding, such as translation initiation inhibitors, lead to shorter mRNA half-lives.

swift degradation of the $h b s$ transcript, which encodes the DNA binding protein HBsu (Daou-Chabo et al., 2009; Braun et al., 2017). In M. smegmatis and M. tuberculosis, RNase E cleaves the furA-kat $G$ operon, producing an unstable furA message that is rapidly degraded while the katG transcript is stabilized as it becomes readily accessible for translation (Sala et al., 2008). Overall, regulation of mRNA stability by translation initiation and SD strength seems to be gene-specific.

While it is generally accepted in E. coli that occlusion of RNase cleavage sites by ribosome occupancy may protect a transcript from degradation (Joyce and Dreyfus, 1998), ribosome association with mRNA has not been shown to regulate mRNA stability globally in response to stress. However, data from B. subtilis suggest an interesting mechanism by which RNase activity could affect translation and therefore mRNA degradation on a transcriptome-wide scale (Bruscella et al., 2011). The infCrpmI-rplT operon, which encodes translation initiation factor 3 (IF-3) along with two ribosomal proteins, is expressed from two promoters. The resulting transcripts have different sensitivities to RNase Y, and the RNase Y-sensitive transcript is not competent for translation of IF-3. As a result, inhibition of RNase Y expression alters the relative abundance of the two transcript and causes reduced translation of IF-3. If this were to cause globally reduced translation due to IF-3 deficiency, mRNA decay could be globally increased as a result, although this effect would presumably be counteracted by the globally reduced RNase Y activity. Complex interplays between RNase levels and translation may therefore have the potential to globally impact mRNA decay in B. subtilis.

RNA-binding proteins (RBPs), stalled ribosomes, and SDlike sequences in close proximity to transcript $5^{\prime}$ ends can also alter mRNA fate (Sharp and Bechhofer, 2005). In B. subtilis, interaction of the RBP Glp with the $5^{\prime}$ UTR of $g l p D$, encoding glycerol-3-phosphate dehydrogenase, increases the transcript's stability (Glatz et al., 1996). Other RBPs can modulate the stability of target genes during stress conditions (Figure 3B). For example, $\mathrm{H}-\mathrm{NS}$, a histone-like protein, regulates the RNA stability of $r p o S$ in $E$. coli and $V$. cholerae in stressful environments (Brescia et al., 2004; Silva et al., 2008; Wang et al., 2012). The carbon storage regulator CsrA is an RBP that regulates gene expression posttranscriptionally in $E$. coli and other $\gamma$-Proteobacteria in response to environmental changes, described in Timmermans and Van Melderen (2010) and Romeo and Babitzke (2018). CsrA regulatory roles are best studied in E. coli. The glgCAP transcript, encoding genes implicated in the biosynthesis of glycogen, is destabilized when bound by CsrA (Liu et al., 1995). This response is halted when E. coli enters stationary phase, where CsrA is sequestered by the sRNA CsrB in a ribonucleoprotein complex (Liu et al., 1997). Conversely, CsrA was shown to stabilize some transcripts. CsrA directly binds the $p g a A$ transcript, increasing its half-life along with the rest of the pgaABC polycistron, encoding genes associated to biofilm formation (Wang et al., 2005). Similarly, CsrA stabilizes the $f l h D C$ transcript, encoding the flagellar activation genes $\mathrm{FlhD}_{2} \mathrm{C}_{2}$ (Wei et al., 2001). More recently, a transcriptome-wide study together with bioinformatics predictions showed a major role for CsrA as an mRNA stabilization factor in E. coli (M9 minimal media, doubling time of $6.9 \mathrm{~h}$ ) for more than a thousand transcripts, of which many were predicted to have at least one putative CsrA binding site (Esquerre et al., 2016). CsrA could directly bind transcripts and protect them from RNases, or could affect mRNA stability indirectly by modulating expression or activity of other post-transcriptional regulators, e.g., the RNA chaperone Hfq, encoded by $h f q$. In E. coli, CsrA can bind the $h f q$ mRNA at a single binding site that overlaps its SD region, preventing ribosome access and decreasing its half-life, however, in stationary phase CsrA is sequestered, allowing higher expression of Hfq (Baker et al., 2007). Regulatory roles for CsrA in gram-positive bacteria have only recently been reported. In B. subtilis, CsrA mediates the interaction of the sRNA SR1 and the $a h r C$ mRNA, encoding a transcription regulator of arginine metabolism, to regulate the expression of the arginine catabolic operons (Muller et al., 2019). However, CsrA-SR1 only mildly increased $a h r C$ half-life, and it had no impact on SR1 degradation, indicating that the regulation was primarily at the level of protein synthesis (Muller et al., 2019).

The homohexameric Hfq, highly studied in E. coli and present in a large number of bacteria (Sun et al., 2002), is an important regulator of mRNA-sRNA pairing. The multiple roles of $\mathrm{Hfq}$ include modulation of sRNA-mediated translation blockage or promotion, and regulation of transcript degradation as a direct consequence of altered translation or through 
translation-independent mechanisms. For example, guiding a cognate sRNA to the $5^{\prime}$ region of mRNAs can result either in translation disruption by preventing the $30 \mathrm{~S}$ subunit from binding (Figure 4B), or the opposite outcome by disruption of stem-loops that inhibit its binding (Wassarman et al., 2001; Arluison et al., 2002; Moller et al., 2002; Schumacher et al., 2002; Zhang et al., 2003; Afonyushkin et al., 2005; Sittka et al., 2008). Hfq can also allow RNase E access to specific mRNAs, or modulate the synthesis of Poly(A) tails, assisting PNPase in $3^{\prime}-5^{\prime}$ degradation, as it will be discussed shortly. The physical properties, sequence specificity, protein interaction partners, sRNAs/mRNAs binding kinetics, and other important aspects of Hfq function will not be described here, as they are well described elsewhere; we refer the reader to the following detailed reviews (Vogel and Luisi, 2011; Updegrove et al., 2016; Kavita et al., 2018; Santiago-Frangos and Woodson, 2018).

A common outcome of Hfq sRNA/mRNA interactions is specific regulation of mRNA half-life (Figure 4C). For example, the destabilization of $p t s G$, encoding a glucose permease, in E. coli is mediated by the sRNA SgrS as a response to phosphosugar accumulation (Vanderpool and Gottesman, 2004). Similarly, degradation of ompA was also shown to be impacted by the specific binding of the sRNA MicA to its translational start site, blocking binding of the $30 \mathrm{~S}$ ribosomal subunit and recruiting $\mathrm{Hfq}$ to promote RNase E cleavage (Lundberg et al., 1990; Vytvytska et al., 2000; Udekwu et al., 2005). While the regulatory roles of Hfq are widely accepted for other gram-negative bacteria as well (Sonnleitner et al., 2006; Cui et al., 2013), in grampositive bacteria $\mathrm{Hfq}$ is less well characterized. Hfq rescue experiments in E. coli and S. enterica serovar Typhimurium using Hfq from B. subtilis and $S$. aureus, respectively, failed at rescuing the phenotypes (Vecerek et al., 2008; Rochat et al., 2012). These findings suggest important structural and/or functional differences in $\mathrm{Hfq}$ across evolutionarily divergent groups of bacteria. A study in B. subtilis found that the absence of Hfq does not impair growth under almost 2000 conditions including different carbon, nitrogen, phosphorus and sulfur sources, osmolarity or $\mathrm{pH}$ changes in a large phenotypic analysis (Rochat et al., 2015). Similar findings were shown for S. aureus (Bohn et al., 2007). However, Hfq became necessary for survival in stationary phase (Hammerle et al., 2014; Rochat et al., 2015). Surprisingly, the absence of Hfq in rich media conditions did not alter the transcriptome of B. subtilis (Rochat et al., 2015), while in minimal media, 68 mRNAs and a single sRNA were affected (Hammerle et al., 2014). Both of these studies reported transcriptome changes in the absence of Hfq for B. subtilis in stationary phase, particularly for sporulation and TA systems. Nevertheless, these changes do not necessarily confer fitness or increased survival (Rochat et al., 2015). Overall, while Hfq was shown to impact the B. subtilis transcriptome under certain stress conditions, its role as a regulator of transcript stability seems to greatly vary across species. In another gram-positive, the pathogen Listeria monocytogenes, Hfq interacts with the sRNA LhrA, increasing its stability and controlling the fate of its target mRNAs. But, 50 other sRNA seem to function in an Hfq-independent manner (Christiansen et al., 2006; Nielsen et al., 2010; Nielsen et al., 2011). Unexpectedly, hypoxia, stationary phase and low temperature $\left(30^{\circ} \mathrm{C}\right)$ did not affect sRNA levels in a $\Delta h f q$ strain (Toledo-Arana et al., 2009). Hence, it seems that Hfq may have a smaller role in control of mRNA stability, and an overall restricted role in sRNA/mRNA regulation in grampositive bacteria; and it appears to not be required at all in some bacteria, such as mycobacteria, that lack identified Hfq orthologs (Sun et al., 2002).

\section{mRNA Folding Alters mRNA Decay}

mRNA secondary structures can modulate translation and transcript stability (Figure 3D). Previously, we have discussed how specific 5' UTR folding prevents RNase and ribosome accessibility to the lys $C$ transcript (Caron et al., 2012). In other transcripts, secondary structures can also prevent RNase E from carrying out the first endonucleolytic cleavage, delaying subsequent steps in the decay pathways. In Rhodobacter capsulatus, formation of multiple hairpins can prevent endonucleolytic cleavage of the puf operon (Klug and Cohen, 1990). A stem-loop at the $5^{\prime}$ UTR confers stability to recA, coding for the nucleoprotein filament RecA in Acinetobacter baumannii (Ching et al., 2017), as well as vacA, coding for vacuolating cytotoxin A in Helicobacter pylori (Amilon et al., 2015). In the case of $v a c A$, the stem-loop is also essential for transcript stabilization in acidic and osmotic stress (Amilon et al., 2015). The distance between the start codon and secondary structures can also affect mRNA half-life, as was shown for the $\Delta$ ermC mRNA in B. subtilis, where placing a stem-loop too close to the SD decreased transcript stability (Sharp and Bechhofer, 2005). Secondary structure at transcript $3^{\prime}$ ends also affects stability. The mRNA $3^{\prime}$ end hairpins formed by Rho-independent transcriptional terminators typically stabilize transcripts, as $3^{\prime}-5^{\prime}$ RNases have difficulty initiating decay without a single-stranded substrate (Adhya et al., 1979; Farnham and Platt, 1981; Abe and Aiba, 1996). In E. coli, the poly(A) polymerase (PAP I) is an enzyme responsible for synthesizing poly(A) tails in mRNA (Li et al., 1998). The addition of poly(A) tails to bacterial mRNAs facilitates degradation of transcripts with $3^{\prime}$ hairpins, allowing PNPase - an enzyme that also has a minor polyadenylation role and other enzymes to carry out exonucleolytic activity (Donovan and Kushner, 1986; Blum et al., 1999; Figure 6).

Thus, it is possible for poly(A) tails to act as regulators of mRNA stability, making PAP I a promising candidate for posttranscriptional regulation. However, while this enzyme has been characterized in E. coli, PAP I homologs in B. subtilis have not yet been identified (Campos-Guillen et al., 2005). An interesting role of $\mathrm{Hfq}$ in $E$. coli was reported for transcripts carrying long poly(A) tails, as binding to the tail prevents the access of PNPase, thereby increasing mRNA stability (Hajnsdorf and Regnier, 2000; Folichon et al., 2005). However, on shorter poly(A) tails ( $<10 \mathrm{nt}$ ), Hfq has poor accessibility, making the transcripts susceptible to the activity of PNPase and RNase II (Regnier and Hajnsdorf, 2013). Interestingly, in E. coli, the absence of PAP I disrupts the regulatory role of some sRNAs, leading to an unexpected destabilization of some sRNAs and transcripts, e.g., RyhB and MicA (Sinha et al., 2018). This appears to result from accumulation of transcripts that are normally degraded in a PAP I-dependent fashion. The accumulated 


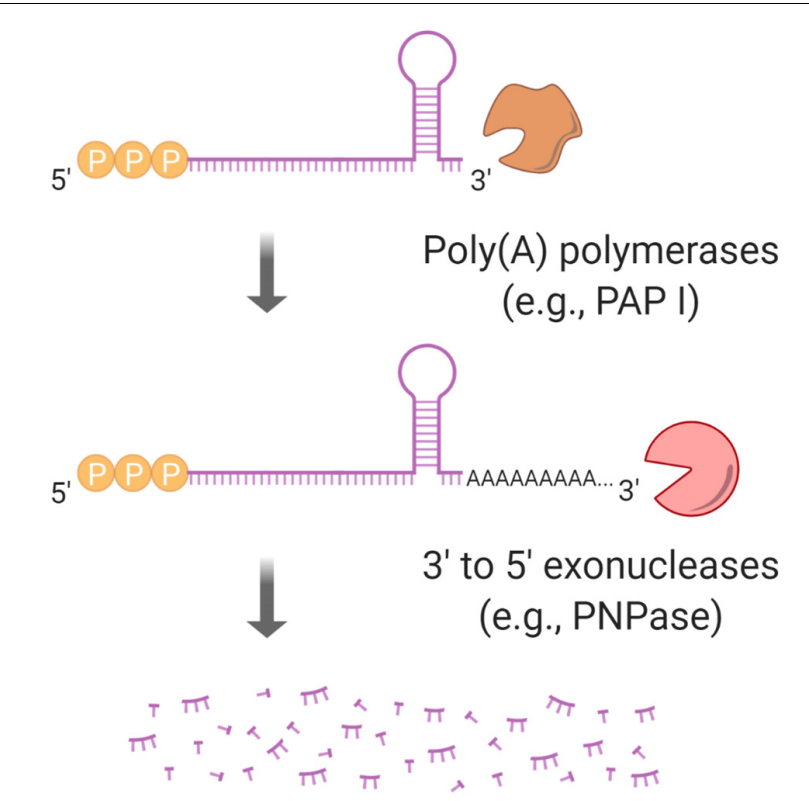

FIGURE 6 | Polyadenylation regulates mRNA half-life. Stem-loops at mRNA 3' ends block $3^{\prime}-5^{\prime}$ exoribonucleases such as PNPase. PAP I, a poly(A) polymerase, can facilitate an exoribonuclease "grip" by synthesizing a poly $(A)$ tail.

transcripts participate in non-specific interactions with sRNAs, leading to degradation of the sRNA-mRNA pairs. Thus, it is suggested that many PAP I targets are transcripts that do not normally interact with sRNAs (Cameron et al., 2019).

Regulation of PNPase abundance has been shown for E. coli, as its transcript $p n p$ is post-transcriptionally regulated by its own product and RNase III. This mechanism can be disrupted by transcript association with the ribosomal protein S1 (Briani et al., 2008; Carzaniga et al., 2015). Moreover, an increase of the pool of polyadenylated transcripts increases $p n p$ half-life, an effect attributed to PNPase titration (Mohanty and Kushner, 2000, 2002). Regardless of this autoregulatory characteristic, changes in PNPase abundance were not detected as a response to hypoxic stress in M. smegmatis (Vargas-Blanco et al., 2019), despite increased mRNA stability. While these findings suggest that regulation by mRNA polyadenylation via PNPase abundance is not a mechanism of transcriptome stabilization in mycobacteria, it is possible that polyadenylation activity by other enzymes, such as PcnA and PcnB, Adilakshmi et al. (2000) might have a role in regulation of mRNA turnover in stress. Further research is needed to investigate this possibility.

\section{The Relationship Between mRNA Abundance and mRNA Decay Rates}

In bacteria, the steady-state mRNA concentration is a function of transcription rates and transcript degradation rates, and to a lesser extent, of mRNA dilution. The contribution of mRNA dilution occurring during cell growth is usually ignored, given that doubling times are significantly longer than the median mRNA half-life. For example, in L. lactis mRNA half-lives complied with this assumption for $85 \%$ of the measured transcripts, at multiple growth rates (Dressaire et al., 2013). In stress conditions, bacterial growth is generally impaired, making the impact of mRNA dilution even smaller and reinforcing the roles of transcription and RNA turnover as the major determinants of mRNA abundance. Also under stress conditions, transcript abundance per cell is typically lower than in conditions of rapid growth. For example, low transcript abundance was observed for $S$. aureus in cold shock, heat shock, and stringent response when compared to unstressed exponential phase (Anderson et al., 2006). The per-cell mRNA concentration decreased in L. lactis during progressive adaptation to carbon starvation (Redon et al., 2005a) or isoleucine starvation (Dressaire et al., 2013). The mRNA concentration was three times higher for $E$. coli growing in LB when compared to growth in in minimal media (Bartholomaus et al., 2016). For $M$. smegmatis in early hypoxic stress, the levels of atpB, atpE, $r n j$, rraA, and sigA ranged between $\sim 5$ and $75 \%$ of those in cells growing in aerobic conditions, and after extended periods of hypoxic or carbon starvation stress, mRNA levels dropped to under $5 \%$ of those in log phase (Vargas-Blanco et al., 2019). Given the generally longer half-lives of mRNAs in stressed bacteria, the observation of reduced mRNA concentrations in these conditions may seem counter-intuitive. However, these observations can be reconciled if transcription is also greatly reduced. It is possible that maintaining lower overall mRNA abundance in stress conditions is an adaptive mechanism to favor translation of genes needed for survival of that particular stressor. For example, in a transcriptome-wide study in E. coli, mRNA abundance decreased in response to osmotic stress (from $\sim 2,400$ to 1,600 transcripts per cell), a change that may allow specific transcripts - associated with stress response - to be more accessible to ribosomes and translated (Bartholomaus et al., 2016). Interestingly, transcripts with higher copy numbers per cell in normal conditions ( $>2$ copies/cell) were downregulated the most in osmotic stress (Bartholomaus et al., 2016).

The question has arisen if lower mRNA concentrations can actually cause their degradation to be slowed. This idea is suggested by an observation made by several groups, in several species, that in log phase growth, mRNA half-lives are inversely correlated with steady-state abundance (Figure 7). For example, a weak negative correlation was shown between mRNA concentration and mRNA half-life for $E$. coli cells in exponential phase (Bernstein et al., 2002). Stronger negative correlations were reported in L. lactis (Redon et al., 2005b), and in M. tuberculosis (Rustad et al., 2013), both in exponentially growing bacteria. Moreover, in the latter study the overexpression of genes in the DosR regulon resulted in transcripts with shorter half-lives. Other reports in E. coli and L. lactis showed that cells growing at different growth rates also show a negative correlation between these parameters (Dressaire et al., 2013; Esquerre et al., 2015). For example, changes in growth rate from 0.1 to $0.63 \mathrm{~h}^{-1}-$ using chemostats - resulted in increased mRNA levels and a decreased median mRNA half-life from 4.2 to $2.8 \mathrm{~min}$, respectively (Esquerre et al., 2014, 2015). Transcription modulation using five constructs with distinct $5^{\prime}$ UTRs in lacLM mRNA also depicted a similar trend in L. lactis in exponential phase, and a 


\section{mRNA abundance and half-life inversely correlated}

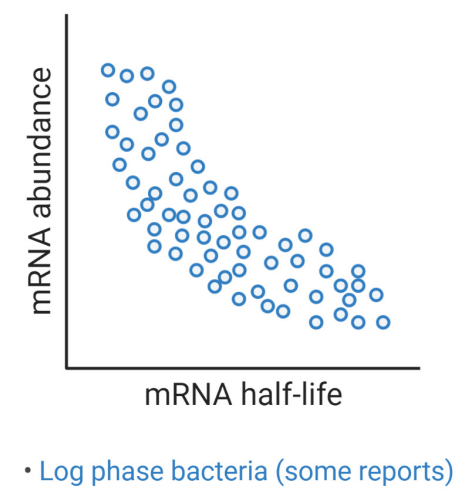

mRNA abundance and half-life uncorrelated (or weak positive correlation)

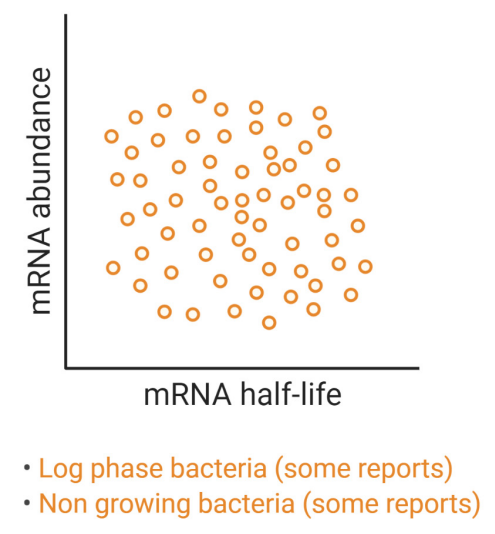

FIGURE 7 | Relationships between mRNA abundance and mRNA decay rates. While some reports have shown a clear negative correlation between a transcript half-life and its abundance, a similar number of reports have found no correlation at all or a modest positive correlation, even for the same organism. Table 1 compiles transcriptome-wide analyses of mRNA decay in different organisms, techniques used, and information on the reported relationships between mRNA abundance and mRNA half-life.

similar outcome was obtained for lacZ in E. coli, using $\mathrm{P}_{\mathrm{BAD}}$ mediated transcription regulation (Nouaille et al., 2017). Two of the studies described here (Rustad et al., 2013; Nouaille et al., 2017) reported inverse relationships between mRNA abundance and half-life in defined systems where expression was modulated by inducible promotors and growth rate was not affected. This strongly suggested that transcription rate can directly influence degradation rate. However, contradictory findings have been reported.

An E. coli transcriptome-wide mRNA half-life study by a different group reported that the rate of mRNA degradation had a very weak positive correlation with mRNA abundance for both exponential phase $\left(R^{2}=0.07\right)$ and stationary phase $\left(R^{2}=0.19\right)$ (Chen et al., 2015), in contrast to other E. coli studies (Bernstein et al., 2002; Esquerre et al., 2014, 2015). In Bacillus cereus, mRNA half-life had a positive correlation with expression level (Kristoffersen et al., 2012), while in Stenotrophomonas maltophilia and Chlamydia trachomatis trachoma and lymphogranuloma venereum biovars no correlations were found (Bernardini and Martinez, 2017; Ferreira et al., 2017). In M. smegmatis, induced overexpression of $d \operatorname{Cas} 9$ (in the absence of a gene-targeting sgRNA) did not alter its half-life in log phase (Vargas-Blanco et al., 2019). Surprisingly, overexpressing $d$ Cas 9 under hypoxic stress increased its mRNA stability by approximately twofold (Vargas-Blanco et al., 2019). Moreover, re-exposure of hypoxic M. smegmatis cultures to oxygen caused half-lives of several tested genes to immediately return to log-phase like levels, despite transcription being blocked by rifampicin and transcript levels therefore remaining low (Vargas-Blanco et al., 2019). Other reports have indicated that the relationship between mRNA abundance and half-life differs in various stress conditions. In carbon-starved L. lactis there was a positive correlation between mRNA degradation and abundance (Redon et al., 2005b), while the opposite was observed during isoleucine starvation (Dressaire et al., 2013). Work in eukaryotes suggests complexities that could conceivably occur in bacteria as well. In S. cerevisiae, under DNA damaging conditions, upregulated genes are usually stabilized and repressed genes are prone to degradation (Shalem et al., 2008). Conversely, under oxidative stress upregulated genes are destabilized, with the opposite scenario for repressed genes (Shalem et al., 2008). Furthermore, an in-depth analysis in that work revealed a trend between these two stress conditions: Genes with a rapid transcriptional regulation show a negative correlation between mRNA abundance and mRNA degradation. On the other hand, genes subject to a slow transcriptional response follow a positive correlation between mRNA abundance and degradation (Shalem et al., 2008).

Clearly, further work is needed to reconcile contradictory findings in bacteria with respect to the relationships between mRNA abundance and stability. Some reported differences may be attributable to differences between species, while others may result from differences in methodology for measuring half-life. Most studies measure half-life by measuring decreases in mRNA abundance following transcription blockage by rifampicin. Variability may arise from the time-points chosen to assay abundance following transcriptional block, given that we and others have reported multiphasic decay kinetics (Hambraeus et al., 2003; Selinger et al., 2003; Chen et al., 2015; Nguyen et al., 2020). Methodology for normalization and for calculating half-lives also vary (see Table 1).

\section{THE IMPORTANCE OF RNA DECAY IN CLINICALLY IMPORTANT SPECIES}

Pathogenic bacteria have developed mechanisms that allow them to survive often-hostile host environments by sensing cues 
and mounting specific responses at both transcriptional and posttranscriptional levels. These pathogens exhibit highly specific responses to some stressors, as well as broader responses to conditions such as energy stress, where resources are preserved by global modulation of processes including translation, protein degradation, transcription, and RNA stabilization (Bohne et al., 1994; Sherman et al., 2001; Park et al., 2003; Christiansen et al., 2004; Wood et al., 2005; Papenfort et al., 2006; Liu et al., 2010; Fritsch et al., 2011; Galagan et al., 2013; Guo et al., 2014; Sievers et al., 2015; Quereda et al., 2018; Ignatov et al., 2020).

In L. monocytogenes, PrfA serves as a transcriptional regulator of multiple virulence factors, such as phospholipases PlcA and $\mathrm{PlcB}$, and the toxin listeriolysin $\mathrm{O}$ (Leimeister-Wachter et al., 1990, 1991; Quereda et al., 2018). Expression of PrfA itself is regulated by several mechanisms at the translational and transcriptional level. For example, PrfA translation is temperature-regulated by a stem-loop in its transcript, $\operatorname{prfA}$, that prevents ribosome access to the SD sequence at $30^{\circ} \mathrm{C}$ but not at $37^{\circ} \mathrm{C}$ (Johansson et al., 2002). prfA is also regulated by an S-adenosylmethionine riboswitch and its product, the sRNA SreA, that blocks translation after binding the $5^{\prime}$ UTR (Loh et al., 2009). Additionally, while the stem-loop increases prfA stability (Loh et al., 2012), the binding of SreA to prfA triggers transcript degradation (Loh et al., 2009). Also in L. monocytogenes, posttranscriptional regulation of Tcsa, the $\mathrm{T}$ cell-stimulating antigen encoded by $t c s A$, was recently reported to be under the control of the sRNA LhrC in a translation-independent manner, by recruiting an undefined RNase (Ross et al., 2019). In S. aureus SarA, a histone-like protein, influences mRNA turnover of virulence factors, such as protein $\mathrm{A}(\mathrm{spa})$ and the collagen adhesion protein ( $\mathrm{cna}$ ) during exponential growth (Roberts et al., 2006; Morrison et al., 2012). Also in S. aureus, the multifunctional RNAIII binds other RNAs, recruiting RNase III to initiate transcript degradation. Some of RNAIII's targets are spa, coa (encoding coagulase), $s b i$ (encoding the IgG-binding protein $\mathrm{Sbi}$ ), and SA1000 (encoding the fibrinogen-binding protein SA1000) (Huntzinger et al., 2005; Boisset et al., 2007; Chevalier et al., 2010), playing an important role in S. aureus virulence and response to stress. In $S$. enterica, under low $\mathrm{Mg}^{2+}$ conditions synthesis of the antisense AmgR RNA leads to interaction and destabilization of the $m g t C$ transcript (encoding the virulence protein $\mathrm{MgtC}$ ), in an RNase E-dependent manner (Lee and Groisman, 2010). Hence, regulation of the stabilities of specific mRNAs has a major role in the survival and virulence responses of pathogens.

Recent reports have suggested unexpected relationships between RNases and drug resistance. Nonsense and INDEL mutations in $R v 2752 c$, encoding RNase J, were associated with drug resistance in a GWAS study that identified resistanceassociated mutations in whole-genome sequences of hundreds of M. tuberculosis clinical isolates (Hicks et al., 2018), as well as an earlier study performing similar analyses on a smaller set of clinical isolates (Zhang et al., 2013). Another study, reporting whole-genome sequences of $154 \mathrm{M}$. leprae clinical isolates from 25 countries, found a disproportionately high number of polymorphisms in ML1040c, encoding RNase D, and ML1512c, encoding RNase J (Benjak et al., 2018). These mutations were not directly associated with drug resistance, but appeared to be under positive selection (Benjak et al., 2018).

Global mRNA stabilization is another feature associated with bacterial stress response and non-growing conditions (see Table 1). Cells in quiescent states contain relatively low levels of mRNA, with greatly reduced transcriptional and translational activity (Betts et al., 2002; Wood et al., 2005; Kumar et al., 2012; Rittershaus et al., 2013). In some cases, these states share similarities with $B$. subtilis spores, in which the bacteria have dramatically reduced mRNA turnover (Segev et al., 2012). This can be interpreted as a concerted cellular effort to downregulate global gene expression and preserve cellular resources, until encountering a suitable environment to resume growth. At the same time, having paused translational machinery may permit allocation of resources toward specific responses needed to survive a given condition, such as those described in the previous paragraph. Importantly, stress responses that establish and maintain non-growing states not only allow pathogens to survive these stressors, but also induce broad antibiotic tolerance, since most antibiotics are relatively ineffective at killing non-growing cells (for example, Rao et al., 2008). This relationship between growth arrest and antibiotic tolerance may be one of the reasons why months of multidrug therapy are required to prevent relapse in tuberculosis patients, where large numbers of bacteria are likely semi-dormant in hypoxic granulomas (Garton et al., 2008). The apparent universality of mRNA stabilization as a response to energy stress and other stressors that inhibit growth, compared to gene-specific mRNA regulation, brings up fascinating possibilities as a prospective target for therapeutic development. There has been a surge in antimicrobial resistance in recent decades, prompting collaborative efforts between academia and industry to develop new antimicrobials (Ventola, 2015a,b; World Health Organization [WHO], 2019). As we approach an understanding of the mechanisms behind mRNA turnover - and strive to unveil how transcript fate is regulated under stress conditions - we would like to emphasize the essentiality of mRNA degradation in bacteria, and the roles of RNases in the virulence and survival responses of pathogens. Many clinically important antibiotics target transcription and translation, highlighting the potential of targeting these central dogma processes from the opposite angle. In early steps in this direction, a protein degradation inhibitor was found to have strong activity against mycobacteria (Gavrish et al., 2014) and inhibitors of RNase $\mathrm{E}$ have been reported (Kime et al., 2015).

\section{CONCLUSION}

Transcriptome stabilization as a stress response is widespread across the bacterial domain. This globally concerted response is implicated in gene regulation and survival, as well as pathogenesis in bacteria. We have described and discussed various mechanisms of mRNA degradation and stabilization, many of which have established roles in regulation of specific genes, but have not yet been able to explain transcriptome-wide half-life alterations. 
We hope that the information presented here helps to inspire further study that will uncover the mechanism(s) behind global transcriptome stabilization in stress, which so far remains elusive. Finally, we hope to inspire the reader to find these mysteries as scientifically stimulating as we do.

\section{AUTHOR CONTRIBUTIONS}

DV-B and SS wrote the manuscript. Both authors contributed to the article and approved the submitted version.

\section{REFERENCES}

Abe, H., and Aiba, H. (1996). Differential contributions of two elements of rhoindependent terminator to transcription termination and mRNA stabilization. Biochimie 78, 1035-1042. doi: 10.1016/s0300-9084(97)86727-2

Adhya, S., Sarkar, P., Valenzuela, D., and Maitra, U. (1979). Termination of transcription by Escherichia coli RNA polymerase: influence of secondary structure of RNA transcripts on rho-independent and rho-dependent termination. Proc. Natl. Acad. Sci. U.S.A. 76, 1613-1617. doi: 10.1073/pnas.76. 4.1613

Adilakshmi, T., Ayling, P. D., and Ratledge, C. (2000). Polyadenylylation in mycobacteria: evidence for oligo(dT)-primed cDNA synthesis. Microbiology 146(Pt 3), 633-638. doi: 10.1099/00221287-146-3-633

Afonyushkin, T., Vecerek, B., Moll, I., Blasi, U., and Kaberdin, V. R. (2005). Both RNase E and RNase III control the stability of sodB mRNA upon translational inhibition by the small regulatory RNA RyhB. Nucleic Acids Res. 33, 1678-1689. doi: 10.1093/nar/gki313

Agaisse, H., and Lereclus, D. (1996). STAB-SD: a Shine-Dalgarno sequence in the $5^{\prime}$ untranslated region is a determinant of mRNA stability. Mol. Microbiol. 20, 633-643. doi: 10.1046/j.1365-2958.1996.5401046.x

Aiso, T., Yoshida, H., Wada, A., and Ohki, R. (2005). Modulation of mRNA stability participates in stationary-phase-specific expression of ribosome modulation factor. J. Bacteriol. 187, 1951-1958. doi: 10.1128/JB.187.6.1951-1958.2005

Ait-Bara, S., and Carpousis, A. J. (2015). RNA degradosomes in bacteria and chloroplasts: classification, distribution and evolution of RNase E homologs. Mol. Microbiol. 97, 1021-1135. doi: 10.1111/mmi.13095

Albertson, M. H., Nyström, T., and Kjelleberg, S. (1990). Functional mRNA halflives in the marine Vibrio sp. S14 during starvation and recovery. Microbiology 136, 2195-2199. doi: 10.1099/00221287-136-11-2195

Al-Husini, N., Tomares, D. T., Bitar, O., Childers, W. S., and Schrader, J. M. (2018). alpha-proteobacterial RNA degradosomes assemble liquid-liquid phaseseparated RNP bodies. Mol. Cell 71, 1027-1039.e14. doi: 10.1016/j.molcel.2018. 08.003

Amilon, K. R., Letley, D. P., Winter, J. A., Robinson, K., and Atherton, J. C. (2015). Expression of the Helicobacter pylori virulence factor vacuolating cytotoxin A ( $\operatorname{vacA}$ ) is influenced by a potential stem-loop structure in the $5^{\prime}$ untranslated region of the transcript. Mol. Microbiol. 98, 831-846. doi: 10.1111/mmi. 13160

Anderson, K. L., Roberts, C., Disz, T., Vonstein, V., Hwang, K., Overbeek, R., et al. (2006). Characterization of the Staphylococcus aureus heat shock, cold shock, stringent, and SOS responses and their effects on log-phase mRNA turnover. J. Bacteriol. 188, 6739-6756. doi: 10.1128/JB.00609-06

Arango, D., Sturgill, D., Alhusaini, N., Dillman, A. A., Sweet, T. J., Hanson, G., et al. (2018). Acetylation of cytidine in mRNA promotes translation efficiency. Cell 175, 1872-1886.e24. doi: 10.1016/j.cell.2018.10.030

Arluison, V., Derreumaux, P., Allemand, F., Folichon, M., Hajnsdorf, E., and Regnier, P. (2002). Structural modelling of the m-like protein Hfq from Escherichia coli. J. Mol. Biol. 320, 705-712. doi: 10.1016/s0022-2836(02) 00548-X

Arnold, T. E., Yu, J., and Belasco, J. G. (1998). mRNA stabilization by the ompA 5 ' untranslated region: two protective elements hinder distinct pathways for mRNA degradation. RNA 4, 319-330.

\section{FUNDING}

This work was supported by the NSF CAREER award 1652756 to SS. DV-B was partially supported by the Fulbright Foreign Student Program.

\section{ACKNOWLEDGMENTS}

We thank all members of the Shell lab for technical assistance and helpful discussions. The figures were created with BioRender.com.

Arraiano, C. M., Andrade, J. M., Domingues, S., Guinote, I. B., Malecki, M., Matos, R. G., et al. (2010). The critical role of RNA processing and degradation in the control of gene expression. FEMS Microbiol. Rev. 34, 883-923. doi: 10.1111/j. 1574-6976.2010.00242.x

Artsimovitch, I., Patlan, V., Sekine, S., Vassylyeva, M. N., Hosaka, T., Ochi, K., et al. (2004). Structural basis for transcription regulation by alarmone ppGpp. Cell 117, 299-310. doi: 10.1016/s0092-8674(04)00401-5

Atkinson, G. C., Tenson, T., and Hauryliuk, V. (2011). The RelA/SpoT homolog (RSH) superfamily: distribution and functional evolution of ppGpp synthetases and hydrolases across the tree of life. PLoS One 6:e23479. doi: 10.1371/journal. pone.0023479

Avarbock, D., Avarbock, A., and Rubin, H. (2000). Differential regulation of opposing RelMtb activities by the aminoacylation state of a tRNA.ribosome.mRNA.RelMtb complex. Biochemistry 39, 11640-11648. doi: 10.1021/bi001256k

Baga, M., Goransson, M., Normark, S., and Uhlin, B. E. (1988). Processed mRNA with differential stability in the regulation of E. coli pilin gene expression. Cell 52, 197-206. doi: 10.1016/0092-8674(88)90508-9

Baker, C. S., Eory, L. A., Yakhnin, H., Mercante, J., Romeo, T., and Babitzke, P. (2007). CsrA inhibits translation initiation of Escherichia coli hfq by binding to a single site overlapping the Shine-Dalgarno sequence. J. Bacteriol. 189, 5472-5481. doi: 10.1128/JB.00529-07

Bandyra, K. J., Bouvier, M., Carpousis, A. J., and Luisi, B. F. (2013). The social fabric of the RNA degradosome. Biochim. Biophys. Acta 1829, 514-522. doi: 10.1016/j.bbagrm.2013.02.011

Bardwell, J. C., Regnier, P., Chen, S. M., Nakamura, Y., Grunberg-Manago, M., and Court, D. L. (1989). Autoregulation of RNase III operon by mRNA processing. EMBO J. 8, 3401-3407. doi: 10.1002/j.1460-2075.1989.tb08504.x

Bartholomaus, A., Fedyunin, I., Feist, P., Sin, C., Zhang, G., Valleriani, A., et al. (2016). Bacteria differently regulate mRNA abundance to specifically respond to various stresses. Philos. Trans. A Math. Phys. Eng. Sci. 374:20150069. doi: 10.1098/rsta.2015.0069

Battesti, A., and Bouveret, E. (2009). Bacteria possessing two RelA/SpoT-like proteins have evolved a specific stringent response involving the acyl carrier protein-SpoT interaction. J. Bacteriol. 191, 616-624. doi: 10.1128/JB.011 95-08

Bechhofer, D. H., and Deutscher, M. P. (2019). Bacterial ribonucleases and their roles in RNA metabolism. Crit. Rev. Biochem. Mol. Biol. 54, 242-300. doi: 10.1080/10409238.2019.1651816

Bechhofer, D. H., and Dubnau, D. (1987). Induced mRNA stability in Bacillus subtilis. Proc. Natl. Acad. Sci. U.S.A. 84, 498-502. doi: 10.1073/pnas.84.2.498

Bechhofer, D. H., and Zen, K. H. (1989). Mechanism of erythromycin-induced ermC mRNA stability in Bacillus subtilis. J. Bacteriol. 171, 5803-5811. doi: 10.1128/jb.171.11.5803-5811.1989

Becker, H. F., Motorin, Y., Planta, R. J., and Grosjean, H. (1997). The yeast gene YNL292w encodes a pseudouridine synthase (Pus4) catalyzing the formation of psi55 in both mitochondrial and cytoplasmic tRNAs. Nucleic Acids Res. 25, 4493-4499. doi: 10.1093/nar/25.22.4493

Belasco, J. G., Beatty, J. T., Adams, C. W., von Gabain, A., and Cohen, S. N. (1985) Differential expression of photosynthesis genes in $R$. capsulata results from segmental differences in stability within the polycistronic rxcA transcript. Cell 40, 171-181. doi: 10.1016/0092-8674(85)90320-4 
Benjak, A., Avanzi, C., Singh, P., Loiseau, C., Girma, S., Busso, P., et al. (2018). Phylogenomics and antimicrobial resistance of the leprosy bacillus Mycobacterium leprae. Nat. Commun. 9:352. doi: 10.1038/s41467-01702576-z

Bernardini, A., and Martinez, J. L. (2017). Genome-wide analysis shows that RNase $G$ plays a global role in the stability of mRNAs in Stenotrophomonas maltophilia. Sci. Rep. 7:16016. doi: 10.1038/s41598-017-16091-0

Bernstein, J. A., Khodursky, A. B., Lin, P. H., Lin-Chao, S., and Cohen, S. N. (2002). Global analysis of mRNA decay and abundance in Escherichia coli at single-gene resolution using two-color fluorescent DNA microarrays. Proc. Natl. Acad. Sci. U.S.A. 99, 9697-9702. doi: 10.1073/pnas.112318199

Bernstein, J. A., Lin, P. H., Cohen, S. N., and Lin-Chao, S. (2004). Global analysis of Escherichia coli RNA degradosome function using DNA microarrays. Proc. Natl. Acad. Sci. U.S.A. 101, 2758-2763. doi: 10.1073/pnas.030874 7101

Betts, J. C., Lukey, P. T., Robb, L. C., McAdam, R. A., and Duncan, K. (2002). Evaluation of a nutrient starvation model of Mycobacterium tuberculosis persistence by gene and protein expression profiling. Mol. Microbiol. 43, 717731. doi: 10.1046/j.1365-2958.2002.02779.X

Bird, J. G., Zhang, Y., Tian, Y., Panova, N., Barvik, I., Greene, L., et al. (2016). The mechanism of RNA $5^{\prime}$ capping with NAD+, NADH and desphospho-CoA. Nature 535, 444-447. doi: 10.1038/nature18622

Blum, E., Carpousis, A. J., and Higgins, C. F. (1999). Polyadenylation promotes degradation of $3^{\prime}$-structured RNA by the Escherichia coli mRNA degradosome in vitro. J. Biol. Chem. 274, 4009-4016. doi: 10.1074/jbc.274.7.4009

Bochner, B. R., Lee, P. C., Wilson, S. W., Cutler, C. W., and Ames, B. N. (1984). AppppA and related adenylylated nucleotides are synthesized as a consequence of oxidation stress. Cell 37, 225-232. doi: 10.1016/0092-8674(84)90318-0

Bodi, Z., Button, J. D., Grierson, D., and Fray, R. G. (2010). Yeast targets for mRNA methylation. Nucleic Acids Res. 38, 5327-5335. doi: 10.1093/nar/gkq266

Boel, G., Letso, R., Neely, H., Price, W. N., Wong, K. H., Su, M., et al. (2016). Codon influence on protein expression in E. coli correlates with mRNA levels. Nature 529, 358-363. doi: 10.1038/nature16509

Bohn, C., Rigoulay, C., and Bouloc, P. (2007). No detectable effect of RNAbinding protein Hfq absence in Staphylococcus aureus. BMC Microbiol. 7:10. doi: 10.1186/1471-2180-7-10

Bohne, J., Sokolovic, Z., and Goebel, W. (1994). Transcriptional regulation of prfA and PrfA-regulated virulence genes in Listeria monocytogenes. Mol. Microbiol. 11, 1141-1150. doi: 10.1111/j.1365-2958.1994.tb00390.x

Boisset, S., Geissmann, T., Huntzinger, E., Fechter, P., Bendridi, N., Possedko, M., et al. (2007). Staphylococcus aureus RNAIII coordinately represses the synthesis of virulence factors and the transcription regulator Rot by an antisense mechanism. Genes Dev. 21, 1353-1366. doi: 10.1101/gad.423507

Bouvet, P., and Belasco, J. G. (1992). Control of RNase E-mediated RNA degradation by $5^{\prime}$-terminal base pairing in E. coli. Nature 360, 488-491. doi: $10.1038 / 360488 \mathrm{a} 0$

Braun, F., Durand, S., and Condon, C. (2017). Initiating ribosomes and a 5'/3'-UTR interaction control ribonuclease action to tightly couple B. subtilis hbs mRNA stability with translation. Nucleic Acids Res. 45, 11386-11400. doi: 10.1093/nar/ gkx793

Braun, F., Le Derout, J., and Regnier, P. (1998). Ribosomes inhibit an RNase E cleavage which induces the decay of the rpsO mRNA of Escherichia coli. EMBO J. 17, 4790-4797. doi: 10.1093/emboj/17.16.4790

Brescia, C. C., Kaw, M. K., and Sledjeski, D. D. (2004). The DNA binding protein $\mathrm{H}-\mathrm{NS}$ binds to and alters the stability of RNA in vitro and in vivo. J. Mol. Biol. 339, 505-514. doi: 10.1016/j.jmb.2004.03.067

Brevet, A., Chen, J., Leveque, F., Plateau, P., and Blanquet, S. (1989). In vivo synthesis of adenylylated bis $\left(5^{\prime}\right.$-nucleosidyl) tetraphosphates (Ap4N) by Escherichia coli aminoacyl-tRNA synthetases. Proc. Natl. Acad. Sci. U.S.A. 86, 8275-8279. doi: 10.1073/pnas.86.21.8275

Briani, F., Curti, S., Rossi, F., Carzaniga, T., Mauri, P., and Deho, G. (2008). Polynucleotide phosphorylase hinders mRNA degradation upon ribosomal protein S1 overexpression in Escherichia coli. RNA 14, 2417-2429. doi: 10.1261/ rna.1123908

Bruscella, P., Shahbabian, K., Laalami, S., and Putzer, H. (2011). RNase Y is responsible for uncoupling the expression of translation factor IF3 from that of the ribosomal proteins L35 and L20 in Bacillus subtilis. Mol. Microbiol. 81, 1526-1541. doi: 10.1111/j.1365-2958.2011.07793.x
Cahova, H., Winz, M. L., Hofer, K., Nubel, G., and Jaschke, A. (2015). NAD captureSeq indicates NAD as a bacterial cap for a subset of regulatory RNAs. Nature 519, 374-377. doi: 10.1038/nature14020

Callaghan, A. J., Marcaida, M. J., Stead, J. A., McDowall, K. J., Scott, W. G., and Luisi, B. F. (2005). Structure of Escherichia coli RNase E catalytic domain and implications for RNA turnover. Nature 437, 1187-1191. doi: 10.1038/ nature 04084

Cameron, T. A., Matz, L. M., Sinha, D., and De Lay, N. R. (2019). Polynucleotide phosphorylase promotes the stability and function of Hfq-binding sRNAs by degrading target mRNA-derived fragments. Nucleic Acids Res. 47, 8821-8837. doi: 10.1093/nar/gkz616

Campos-Guillen, J., Bralley, P., Jones, G. H., Bechhofer, D. H., and OlmedoAlvarez, G. (2005). Addition of poly(A) and heteropolymeric $3^{\prime}$ ends in Bacillus subtilis wild-type and polynucleotide phosphorylase-deficient strains. J. Bacteriol. 187, 4698-4706. doi: 10.1128/JB.187.14.4698-4706.2005

Carabetta, V. J., Tanner, A. W., Greco, T. M., Defrancesco, M., Cristea, I. M., and Dubnau, D. (2013). A complex of YlbF, YmcA and YaaT regulates sporulation, competence and biofilm formation by accelerating the phosphorylation of Spo0A. Mol. Microbiol. 88, 283-300. doi: 10.1111/mmi.12186

Carlile, T. M., Rojas-Duran, M. F., Zinshteyn, B., Shin, H., Bartoli, K. M., and Gilbert, W. V. (2014). Pseudouridine profiling reveals regulated mRNA pseudouridylation in yeast and human cells. Nature 515, 143-146. doi: 10.1038/ nature 13802

Caron, M. P., Bastet, L., Lussier, A., Simoneau-Roy, M., Masse, E., and Lafontaine, D. A. (2012). Dual-acting riboswitch control of translation initiation and mRNA decay. Proc. Natl. Acad. Sci. U.S.A. 109, E3444-E3453. doi: 10.1073/pnas. 1214024109

Carpousis, A. J. (2007). The RNA degradosome of Escherichia coli: an mRNAdegrading machine assembled on RNase E. Annu. Rev. Microbiol. 61, 71-87. doi: 10.1146/annurev.micro.61.080706.093440

Carpousis, A. J., Van Houwe, G., Ehretsmann, C., and Krisch, H. M. (1994). Copurification of E. coli RNAase E and PNPase: evidence for a specific association between two enzymes important in RNA processing and degradation. Cell 76, 889-900. doi: 10.1016/0092-8674(94)90363-8

Carzaniga, T., Deho, G., and Briani, F. (2015). RNase III-independent autogenous regulation of Escherichia coli polynucleotide phosphorylase via translational repression. J. Bacteriol. 197, 1931-1938. doi: 10.1128/JB.00105-15

Celesnik, H., Deana, A., and Belasco, J. G. (2007). Initiation of RNA decay in Escherichia coli by $5^{\prime}$ pyrophosphate removal. Mol. Cell 27, 79-90. doi: 10.1016/ j.molcel.2007.05.038

Chakraburtty, R., and Bibb, M. (1997). The ppGpp synthetase gene (relA) of Streptomyces coelicolor A3(2) plays a conditional role in antibiotic production and morphological differentiation. J. Bacteriol. 179, 5854-5861. doi: 10.1128/ jb.179.18.5854-5861.1997

Chan, C. T., Dyavaiah, M., DeMott, M. S., Taghizadeh, K., Dedon, P. C., and Begley, T. J. (2010). A quantitative systems approach reveals dynamic control of tRNA modifications during cellular stress. PLoS Genet. 6:e1001247. doi: 10.1371/journal.pgen.1001247

Chan, C. T., Pang, Y. L., Deng, W., Babu, I. R., Dyavaiah, M., Begley, T. J., et al. (2012). Reprogramming of tRNA modifications controls the oxidative stress response by codon-biased translation of proteins. Nat. Commun. 3:937. doi: 10.1038/ncomms1938

Chandran, V., and Luisi, B. F. (2006). Recognition of enolase in the Escherichia coli RNA degradosome. J. Mol. Biol. 358, 8-15. doi: 10.1016/j.jmb.2006. 02.012

Chao, Y., Li, L., Girodat, D., Forstner, K. U., Said, N., Corcoran, C., et al. (2017). In vivo cleavage map illuminates the central role of RNase $\mathrm{E}$ in coding and non-coding RNA pathways. Mol. Cell 65, 39-51. doi: 10.1016/j.molcel.2016. 11.002

Chen, H., Previero, A., and Deutscher, M. P. (2019). A novel mechanism of ribonuclease regulation: GcvB and Hfq stabilize the mRNA that encodes RNase BN/Z during exponential phase. J. Biol. Chem. 294, 19997-20008. doi: 10.1074/ jbc.RA119.011367

Chen, H., Shiroguchi, K., Ge, H., and Xie, X. S. (2015). Genome-wide study of mRNA degradation and transcript elongation in Escherichia coli. Mol. Syst. Biol. 11:781. doi: 10.15252/msb.20145794

Chen, L. H., Emory, S. A., Bricker, A. L., Bouvet, P., and Belasco, J. G. (1991). Structure and function of a bacterial mRNA stabilizer: analysis of the $5^{\prime}$ 
untranslated region of ompA mRNA. J. Bacteriol. 173, 4578-4586. doi: 10.1128/ jb.173.15.4578-4586.1991

Chen, X., Li, A., Sun, B. F., Yang, Y., Han, Y. N., Yuan, X., et al. (2019). 5methylcytosine promotes pathogenesis of bladder cancer through stabilizing mRNAs. Nat. Cell Biol. 21, 978-990. doi: 10.1038/s41556-019-0361-y

Chen, Y. G., Kowtoniuk, W. E., Agarwal, I., Shen, Y., and Liu, D. R. (2009). LC/MS analysis of cellular RNA reveals NAD-linked RNA. Nat. Chem. Biol. 5, 879-881. doi: 10.1038/nchembio. 235

Chen, Z., Itzek, A., Malke, H., Ferretti, J. J., and Kreth, J. (2013). Multiple roles of RNase $\mathrm{Y}$ in Streptococcus pyogenes mRNA processing and degradation. J. Bacteriol. 195, 2585-2594. doi: 10.1128/jb.00097-13

Chevalier, C., Boisset, S., Romilly, C., Masquida, B., Fechter, P., Geissmann, T., et al. (2010). Staphylococcus aureus RNAIII binds to two distant regions of coa mRNA to arrest translation and promote mRNA degradation. PLoS Pathog. 6:e1000809. doi: 10.1371/journal.ppat.1000809

Ching, C., Gozzi, K., Heinemann, B., Chai, Y., and Godoy, V. G. (2017). RNAMediated cis Regulation in Acinetobacter baumannii Modulates Stress-Induced Phenotypic Variation. J. Bacteriol. 199:e00799-16. doi: 10.1128/JB.00799-16

Chionh, Y. H., McBee, M., Babu, I. R., Hia, F., Lin, W., Zhao, W., et al. (2016). tRNA-mediated codon-biased translation in mycobacterial hypoxic persistence. Nat. Commun. 7:13302. doi: 10.1038/ncomms 13302

Cho, K. H. (2017). The structure and function of the gram-positive bacterial RNA degradosome. Front. Microbiol. 8:154. doi: 10.3389/fmicb.2017.00154

Christiansen, J. K., Larsen, M. H., Ingmer, H., Sogaard-Andersen, L., and Kallipolitis, B. H. (2004). The RNA-binding protein $\mathrm{Hfq}$ of Listeria monocytogenes: role in stress tolerance and virulence. J. Bacteriol. 186, 33553362. doi: 10.1128/JB.186.11.3355-3362.2004

Christiansen, J. K., Nielsen, J. S., Ebersbach, T., Valentin-Hansen, P., SogaardAndersen, L., and Kallipolitis, B. H. (2006). Identification of small Hfq-binding RNAs in Listeria monocytogenes. RNA 12, 1383-1396. doi: 10.1261/rna.49706

Commichau, F. M., Rothe, F. M., Herzberg, C., Wagner, E., Hellwig, D., Lehnik-Habrink, M., et al. (2009). Novel activities of glycolytic enzymes in Bacillus subtilis: interactions with essential proteins involved in mRNA processing. Mol. Cell. Proteomics 8, 1350-1360. doi: 10.1074/mcp.M800546MCP200

Condon, C. (2003). RNA processing and degradation in Bacillus subtilis. Microbiol. Mol. Biol. Rev. 67, 157-174. doi: 10.1128/mmbr.67.2.157-174.2003

Condon, C., Putzer, H., and Grunberg-Manago, M. (1996). Processing of the leader mRNA plays a major role in the induction of thrS expression following threonine starvation in Bacillus subtilis. Proc. Natl. Acad. Sci. U.S.A. 93, 69926997. doi: 10.1073/pnas.93.14.6992

Corrigan, R. M., Bellows, L. E., Wood, A., and Grundling, A. (2016). ppGpp negatively impacts ribosome assembly affecting growth and antimicrobial tolerance in Gram-positive bacteria. Proc. Natl. Acad. Sci. U.S.A. 113, E1710E1719. doi: 10.1073/pnas.1522179113

Coste, H., Brevet, A., Plateau, P., and Blanquet, S. (1987). Non-adenylylated bis(5'-nucleosidyl) tetraphosphates occur in Saccharomyces cerevisiae and in Escherichia coli and accumulate upon temperature shift or exposure to cadmium. J. Biol. Chem. 262, 12096-12103.

Courbet, A., Endy, D., Renard, E., Molina, F., and Bonnet, J. (2015). Detection of pathological biomarkers in human clinical samples via amplifying genetic switches and logic gates. Sci. Transl. Med. 7:289ra283. doi: 10.1126/ scitranslmed.aaa3601

Cui, M., Wang, T., Xu, J., Ke, Y., Du, X., Yuan, X., et al. (2013). Impact of Hfq on global gene expression and intracellular survival in Brucella melitensis. PLoS One 8:e71933. doi: 10.1371/journal.pone.0071933

Daeffler, K. N., Galley, J. D., Sheth, R. U., Ortiz-Velez, L. C., Bibb, C. O., Shroyer, N. F., et al. (2017). Engineering bacterial thiosulfate and tetrathionate sensors for detecting gut inflammation. Mol. Syst. Biol. 13:923. doi: 10.15252/msb. 20167416

Daou-Chabo, R., Mathy, N., Benard, L., and Condon, C. (2009). Ribosomes initiating translation of the hbs mRNA protect it from $5^{\prime}$-to- $3^{\prime}$ exoribonucleolytic degradation by RNase J1. Mol. Microbiol. 71, 1538-1550. doi: 10.1111/j.1365-2958.2009.06620.x

Deana, A., Celesnik, H., and Belasco, J. G. (2008). The bacterial enzyme RppH triggers messenger RNA degradation by $5^{\prime}$ pyrophosphate removal. Nature 451, 355-358. doi: 10.1038/nature06475

DeLoughery, A., Dengler, V., Chai, Y., and Losick, R. (2016). Biofilm formation by Bacillus subtilis requires an endoribonuclease-containing multisubunit complex that controls mRNA levels for the matrix gene repressor SinR. Mol. Microbiol. 99, 425-437. doi: 10.1111/mmi.13240

DeLoughery, A., Jean-Benoît, L., Losick, R., and Gene-Wei, L. (2018). Maturation of polycistronic mRNAs by the endoribonuclease RNase $\mathrm{Y}$ and its associated Y-complex in Bacillus subtilis. Proc. Natl. Acad. Sci. U.S.A. 115, E5585-E5594. doi: $10.1073 /$ pnas. 1803283115

Deng, W., Babu, I. R., Su, D., Yin, S., Begley, T. J., and Dedon, P. C. (2015). Trm9-catalyzed tRNA modifications regulate global protein expression by codon-biased translation. PLoS Genet. 11:e1005706. doi: 10.1371/journal.pgen. 1005706

Deng, X., Chen, K., Luo, G. Z., Weng, X., Ji, Q., Zhou, T., et al. (2015). Widespread occurrence of N6-methyladenosine in bacterial mRNA. Nucleic Acids Res. 43, 6557-6567. doi: 10.1093/nar/gkv596

Deng, Z., Liu, Z., Bi, Y., Wang, X., Zhou, D., Yang, R., et al. (2014). Rapid degradation of Hfq-free RyhB in Yersinia pestis by PNPase independent of putative ribonucleolytic complexes. Biomed Res. Int. 2014:798918. doi: 10.1155/ 2014/798918

Deutscher, M. P. (2006). Degradation of RNA in bacteria: comparison of mRNA and stable RNA. Nucleic Acids Res. 34, 659-666. doi: 10.1093/nar/gkj472

Diwa, A., Bricker, A. L., Jain, C., and Belasco, J. G. (2000). An evolutionarily conserved RNA stem-loop functions as a sensor that directs feedback regulation of RNase E gene expression. Genes Dev. 14, 1249-1260.

Diwa, A. A., and Belasco, J. G. (2002). Critical features of a conserved RNA stemloop important for feedback regulation of RNase E synthesis. J. Biol. Chem. 277, 20415-20422. doi: 10.1074/jbc.M202313200

Donovan, W. P., and Kushner, S. R. (1986). Polynucleotide phosphorylase and ribonuclease II are required for cell viability and mRNA turnover in Escherichia coli K-12. Proc. Natl. Acad. Sci. U.S.A. 83, 120-124. doi: 10.1073/pnas.83.1.120

Drecktrah, D., Hall, L. S., Rescheneder, P., Lybecker, M., and Samuels, D. S. (2018). The stringent response-regulated sRNA transcriptome of Borrelia burgdorferi. Front. Cell. Infect. Microbiol. 8:231. doi: 10.3389/fcimb.2018.00231

Dressaire, C., Picard, F., Redon, E., Loubiere, P., Queinnec, I., Girbal, L., et al. (2013). Role of mRNA stability during bacterial adaptation. PLoS One 8:e59059. doi: 10.1371/journal.pone.0059059

Druzhinin, S. Y., Tran, N. T., Skalenko, K. S., Goldman, S. R., Knoblauch, J. G., Dove, S. L., et al. (2015). A conserved pattern of primer-dependent transcription initiation in Escherichia coli and Vibrio cholerae revealed by 5', RNA-seq. PLoS Genet. 11:e1005348. doi: 10.1371/journal.pgen.1005348

Dubnau, E. J., Carabetta, V. J., Tanner, A. W., Miras, M., Diethmaier, C., and Dubnau, D. (2016). A protein complex supports the production of Spo0A-P and plays additional roles for biofilms and the K-state in Bacillus subtilis. Mol. Microbiol. 101, 606-624. doi: 10.1111/mmi.13411

Durand, S., Gilet, L., Bessieres, P., Nicolas, P., and Condon, C. (2012). Three essential ribonucleases-RNase Y, J1, and III-control the abundance of a majority of Bacillus subtilis mRNAs. PLoS Genet. 8:e1002520. doi: 10.1371/journal.pgen. 1002520

Edelheit, S., Schwartz, S., Mumbach, M. R., Wurtzel, O., and Sorek, R. (2013). Transcriptome-wide mapping of 5-methylcytidine RNA modifications in bacteria, archaea, and yeast reveals m5C within archaeal mRNAs. PLoS Genet. 9:e1003602. doi: 10.1371/journal.pgen.1003602

Emory, S. A., and Belasco, J. G. (1990). The ompA 5' untranslated RNA segment functions in Escherichia coli as a growth-rate-regulated mRNA stabilizer whose activity is unrelated to translational efficiency. J. Bacteriol. 172, 4472-4481. doi: 10.1128/jb.172.8.4472-4481.1990

Emory, S. A., Bouvet, P., and Belasco, J. G. (1992). A 5 '-terminal stem-loop structure can stabilize mRNA in Escherichia coli. Genes Dev. 6, 135-148. doi: 10.1101/gad.6.1.135

Esquerre, T., Bouvier, M., Turlan, C., Carpousis, A. J., Girbal, L., and CocaignBousquet, M. (2016). The Csr system regulates genome-wide mRNA stability and transcription and thus gene expression in Escherichia coli. Sci. Rep. 6:25057. doi: 10.1038/srep25057

Esquerre, T., Laguerre, S., Turlan, C., Carpousis, A. J., Girbal, L., and CocaignBousquet, M. (2014). Dual role of transcription and transcript stability in the regulation of gene expression in Escherichia coli cells cultured on glucose at different growth rates. Nucleic Acids Res. 42, 2460-2472. doi: 10.1093/nar/ gkt1150

Esquerre, T., Moisan, A., Chiapello, H., Arike, L., Vilu, R., Gaspin, C., et al. (2015). Genome-wide investigation of mRNA lifetime determinants in Escherichia coli cells cultured at different growth rates. BMC Genomics 16:275. 
Even, S., Pellegrini, O., Zig, L., Labas, V., Vinh, J., Brechemmier-Baey, D., et al. (2005). Ribonucleases J1 and J2: two novel endoribonucleases in B. subtilis with functional homology to E.coli RNase E. Nucleic Acids Res. 33, 2141-2152. doi: 10.1093/nar/gki505

Eyler, D. E., Franco, M. K., Batool, Z., Wu, M. Z., Dubuke, M. L., DoboszBartoszek, M., et al. (2019). Pseudouridinylation of mRNA coding sequences alters translation. Proc. Natl. Acad. Sci. U.S.A. 116, 23068-23074. doi: 10.1073/ pnas. 1821754116

Faner, M. A., and Feig, A. L. (2013). Identifying and characterizing Hfq-RNA interactions. Methods 63, 144-159. doi: 10.1016/j.ymeth.2013.04.023

Farnham, P. J., and Platt, T. (1981). Rho-independent termination: dyad symmetry in DNA causes RNA polymerase to pause during transcription in vitro. Nucleic Acids Res. 9, 563-577. doi: 10.1093/nar/9.3.563

Farr, S. B., Arnosti, D. N., Chamberlin, M. J., and Ames, B. N. (1989). An apaH mutation causes AppppA to accumulate and affects motility and catabolite repression in Escherichia coli. Proc. Natl. Acad. Sci. U.S.A. 86, 5010-5014. doi: 10.1073/pnas.86.13.5010

Ferreira, R., Borges, V., Borrego, M. J., and Gomes, J. P. (2017). Global survey of mRNA levels and decay rates of Chlamydia trachomatis trachoma and lymphogranuloma venereum biovars. Heliyon 3:e00364. doi: 10.1016/j.heliyon. 2017.e00364

Folichon, M., Allemand, F., Regnier, P., and Hajnsdorf, E. (2005). Stimulation of poly(A) synthesis by Escherichia coli poly(A)polymerase I is correlated with Hfq binding to poly(A) tails. FEBS J. 272, 454-463. doi: 10.1111/j.1742-4658.2004. 04485. $\mathrm{x}$

Frederix, M., and Downie, A. J. (2011). Quorum sensing: regulating the regulators. Adv. Microb. Physiol. 58, 23-80. doi: 10.1016/B978-0-12-381043-4.00002-7

Frindert, J., Zhang, Y., Nubel, G., Kahloon, M., Kolmar, L., Hotz-Wagenblatt, A., et al. (2018). Identification, biosynthesis, and decapping of NAD-capped RNAs in B. subtilis. Cell Rep. 24, 1890-1901.e8. doi: 10.1016/j.celrep.2018.07.047

Fritsch, F., Mauder, N., Williams, T., Weiser, J., Oberle, M., and Beier, D. (2011). The cell envelope stress response mediated by the LiaFSRLm three-component system of Listeria monocytogenes is controlled via the phosphatase activity of the bifunctional histidine kinase LiaSLm. Microbiology 157(Pt 2), 373-386. doi: 10.1099/mic.0.044776-0

Fry, M., Israeli-Reches, M., and Artman, M. (1972). Stabilization and breakdown of Escherichia coli messenger ribonucleic acid in the presence of chloramphenicol. Biochemistry 11, 3054-3059. doi: 10.1021/bi00766a017

Galagan, J. E., Minch, K., Peterson, M., Lyubetskaya, A., Azizi, E., Sweet, L., et al. (2013). The Mycobacterium tuberculosis regulatory network and hypoxia. Nature 499, 178-183. doi: 10.1038/nature 12337

Garton, N. J., Waddell, S. J., Sherratt, A. L., Lee, S. M., Smith, R. J., Senner, C., et al. (2008). Cytological and transcript analyses reveal fat and lazy persisterlike bacilli in tuberculous sputum. PLoS Med. 5:e75. doi: 10.1371/journal.pmed. 0050075

Gatewood, M. L., and Jones, G. H. (2010). (p)ppGpp inhibits polynucleotide phosphorylase from streptomyces but not from Escherichia coli and increases the stability of bulk mRNA in Streptomyces coelicolor. J. Bacteriol. 192, 42754280. doi: 10.1128/JB.00367-10

Gavrish, E., Sit, C. S., Cao, S., Kandror, O., Spoering, A., Peoples, A., et al. (2014). Lassomycin, a ribosomally synthesized cyclic peptide, kills Mycobacterium tuberculosis by targeting the ATP-dependent protease ClpC1P1P2. Chem. Biol. 21, 509-518. doi: 10.1016/j.chembiol.2014.01.014

Gentry, D. R., Hernandez, V. J., Nguyen, L. H., Jensen, D. B., and Cashel, M. (1993). Synthesis of the stationary-phase sigma factor sigma $\mathrm{s}$ is positively regulated by ppGpp. J. Bacteriol. 175, 7982-7989. doi: 10.1128/jb.175.24.7982-7989. 1993

Georgellis, D., Barlow, T., Arvidson, S., and von Gabain, A. (1993). Retarded RNA turnover in Escherichia coli: a means of maintaining gene expression during anaerobiosis. Mol. Microbiol. 9, 375-381. doi: 10.1111/j.1365-2958. 1993.tb01698.x

Glatz, E., Nilsson, R. P., Rutberg, L., and Rutberg, B. (1996). A dual role for the Bacillus subtilis glpD leader and the GlpP protein in the regulated expression of glpD: antitermination and control of mRNA stability. Mol. Microbiol. 19, 319-328. doi: 10.1046/j.1365-2958.1996.376903.x

Gualerzi, C. O., Giuliodori, A. M., and Pon, C. L. (2003). Transcriptional and post-transcriptional control of cold-shock genes. J. Mol. Biol. 331, 527-539. doi: $10.1016 /$ s0022-2836(03)00732-0
Guo, M. S., Updegrove, T. B., Gogol, E. B., Shabalina, S. A., Gross, C. A., and Storz, G. (2014). MicL, a new sigmaE-dependent sRNA, combats envelope stress by repressing synthesis of Lpp, the major outer membrane lipoprotein. Genes Dev. 28, 1620-1634. doi: 10.1101/gad.243485.114

Gutgsell, N., Englund, N., Niu, L., Kaya, Y., Lane, B. G., and Ofengand, J. (2000). Deletion of the Escherichia coli pseudouridine synthase gene truB blocks formation of pseudouridine 55 in tRNA in vivo, does not affect exponential growth, but confers a strong selective disadvantage in competition with wildtype cells. RNA 6, 1870-1881. doi: 10.1017/s1355838200001588

Hadjeras, L., Poljak, L., Bouvier, M., Morin-Ogier, Q., Canal, I., CocaignBousquet, M., et al. (2019). Detachment of the RNA degradosome from the inner membrane of Escherichia coli results in a global slowdown of mRNA degradation, proteolysis of RNase $\mathrm{E}$ and increased turnover of ribosome-free transcripts. Mol. Microbiol. 111, 1715-1731. doi: 10.1111/mmi. 14248

Hajnsdorf, E., and Regnier, P. (2000). Host factor Hfq of Escherichia coli stimulates elongation of poly(A) tails by poly(A) polymerase I. Proc. Natl. Acad. Sci. U.S.A. 97, 1501-1505. doi: 10.1073/pnas.040549897

Hambraeus, G., Karhumaa, K., and Rutberg, B. (2002). A $5^{\prime}$ stem-loop and ribosome binding but not translation are important for the stability of Bacillus subtilis aprE leader mRNA. Microbiology 148(Pt 6), 1795-1803. doi: 10.1099/ 00221287-148-6-1795

Hambraeus, G., Persson, M., and Rutberg, B. (2000). The aprE leader is a determinant of extreme mRNA stability in Bacillus subtilis. Microbiology 146(Pt 12), 3051-3059. doi: 10.1099/00221287-146-12-3051

Hambraeus, G., von Wachenfeldt, C., and Hederstedt, L. (2003). Genome-wide survey of mRNA half-lives in Bacillus subtilis identifies extremely stable mRNAs. Mol. Genet. Genomics 269, 706-714. doi: 10.1007/s00438-003-0883-6

Hammerle, H., Amman, F., Vecerek, B., Stulke, J., Hofacker, I., and Blasi, U. (2014). Impact of Hfq on the Bacillus subtilis transcriptome. PLoS One 9:e98661. doi: 10.1371/journal.pone.0098661

Hamouche, L., Billaudeau, C., Rocca, A., Chastanet, A., Ngo, S., Laalami, S., et al. (2020). Dynamic membrane localization of RNase Y in Bacillus subtilis. mBio 11:e03337-19. doi: 10.1128/mBio.03337-19

Hausmann, S., Guimaraes, V. A., Garcin, D., Baumann, N., Linder, P., and Redder, P. (2017). Both exo- and endo-nucleolytic activities of RNase J1 from Staphylococcus aureus are manganese dependent and active on triphosphorylated $5^{\prime}$-ends. RNA Biol. 14, 1431-1443. doi: 10.1080/15476286. 2017.1300223

Hicks, N. D., Yang, J., Zhang, X., Zhao, B., Grad, Y. H., Liu, L., et al. (2018). Clinically prevalent mutations in Mycobacterium tuberculosis alter propionate metabolism and mediate multidrug tolerance. Nat. Microbiol. 3, 1032-1042. doi: 10.1038/s41564-018-0218-3

Hoernes, T. P., Clementi, N., Faserl, K., Glasner, H., Breuker, K., Lindner, H., et al. (2016). Nucleotide modifications within bacterial messenger RNAs regulate their translation and are able to rewire the genetic code. Nucleic Acids Res. 44, 852-862. doi: 10.1093/nar/gkv1182

Hofer, K., Li, S., Abele, F., Frindert, J., Schlotthauer, J., Grawenhoff, J., et al. (2016). Structure and function of the bacterial decapping enzyme NudC. Nat. Chem. Biol. 12, 730-734. doi: 10.1038/nchembio.2132

Huang, T., Chen, W., Liu, J., Gu, N., and Zhang, R. (2019). Genome-wide identification of mRNA 5-methylcytosine in mammals. Nat. Struct. Mol. Biol. 26, 380-388. doi: 10.1038/s41594-019-0218-x

Hudecek, O., Benoni, R., Reyes-Gutierrez, P. E., Culka, M., Sanderova, H., Hubalek, M., et al. (2020). Dinucleoside polyphosphates act as $5^{\prime}$-RNA caps in bacteria. Nat. Commun. 11:1052. doi: 10.1038/s41467-020-14896-8

Hue, K. K., Cohen, S. D., and Bechhofer, D. H. (1995). A polypurine sequence that acts as a $5^{\prime}$ mRNA stabilizer in Bacillus subtilis. J. Bacteriol. 177, 3465-3471. doi: 10.1128/jb.177.12.3465-3471.1995

Hunt, A., Rawlins, J. P., Thomaides, H. B., and Errington, J. (2006). Functional analysis of 11 putative essential genes in Bacillus subtilis. Microbiology 152(Pt 10), 2895-2907. doi: 10.1099/mic.0.29152-0

Huntzinger, E., Boisset, S., Saveanu, C., Benito, Y., Geissmann, T., Namane, A., et al. (2005). Staphylococcus aureus RNAIII and the endoribonuclease III coordinately regulate spa gene expression. EMBO J. 24, 824-835. doi: 10.1038/ sj.emboj.7600572

Ignatov, D., Vaitkevicius, K., Durand, S., Cahoon, L., Sandberg, S. S., Liu, X., et al. (2020). An mRNA-mRNA interaction couples expression of a virulence 
factor and its chaperone in Listeria monocytogenes. Cell Rep. 30, 4027-4040.e7. doi: 10.1016/j.celrep.2020.03.006

Ishida, K., Kunibayashi, T., Tomikawa, C., Ochi, A., Kanai, T., Hirata, A., et al. (2011). Pseudouridine at position 55 in tRNA controls the contents of other modified nucleotides for low-temperature adaptation in the extremethermophilic eubacterium Thermus thermophilus. Nucleic Acids Res. 39, $2304-$ 2318. doi: $10.1093 /$ nar/gkq1180

Johansson, J., Mandin, P., Renzoni, A., Chiaruttini, C., Springer, M., and Cossart, P. (2002). An RNA thermosensor controls expression of virulence genes in Listeria monocytogenes. Cell 110, 551-561. doi: 10.1016/s0092-8674(02)00905-4

Jona, G., Choder, M., and Gileadi, O. (2000). Glucose starvation induces a drastic reduction in the rates of both transcription and degradation of mRNA in yeast. Biochim. Biophys. Acta 1491, 37-48. doi: 10.1016/s0167-4781(00)00016-6

Jourdan, S. S., and McDowall, K. J. (2008). Sensing of $5^{\prime}$ monophosphate by Escherichia coli RNase G can significantly enhance association with RNA and stimulate the decay of functional mRNA transcripts in vivo. Mol. Microbiol. 67, 102-115. doi: 10.1111/j.1365-2958.2007.06028.x

Joyce, S. A., and Dreyfus, M. (1998). In the absence of translation, RNase E can bypass $5^{\prime}$ mRNA stabilizers in Escherichia coli. J. Mol. Biol. 282, 241-254. doi: 10.1006/jmbi.1998.2027

Julius, C., and Yuzenkova, Y. (2017). Bacterial RNA polymerase caps RNA with various cofactors and cell wall precursors. Nucleic Acids Res. 45, 8282-8290. doi: $10.1093 / \mathrm{nar} / \mathrm{gkx} 452$

Jurgen, B., Schweder, T., and Hecker, M. (1998). The stability of mRNA from the gsiB gene of Bacillus subtilis is dependent on the presence of a strong ribosome binding site. Mol. Gen. Genet. 258, 538-545. doi: 10.1007/s004380050765

Kavita, K., de Mets, F., and Gottesman, S. (2018). New aspects of RNA-based regulation by Hfq and its partner sRNAs. Curr. Opin. Microbiol. 42, 53-61. doi: 10.1016/j.mib.2017.10.014

Khemici, V., Poljak, L., Luisi, B. F., and Carpousis, A. J. (2008). The RNase E of Escherichia coli is a membrane-binding protein. Mol. Microbiol. 70, 799-813. doi: 10.1111/j.1365-2958.2008.06454.x

Khemici, V., Prados, J., Linder, P., and Redder, P. (2015). Decay-initiating endoribonucleolytic cleavage by RNase y is kept under tight control via sequence preference and sub-cellular localisation. PLoS Genet. 11:e1005577. doi: 10.1371/journal.pgen.1005577

Kido, M., Yamanaka, K., Mitani, T., Niki, H., Ogura, T., and Hiraga, S. (1996). RNase E polypeptides lacking a carboxyl-terminal half suppress a mukB mutation in Escherichia coli. J. Bacteriol. 178, 3917-3925. doi: 10.1128/jb.178. 13.3917-3925.1996

Kime, L., Jourdan, S. S., Stead, J. A., Hidalgo-Sastre, A., and McDowall, K. J. (2010). Rapid cleavage of RNA by RNase $\mathrm{E}$ in the absence of $5^{\prime}$ monophosphate stimulation. Mol. Microbiol. 76, 590-604. doi: 10.1111/j.1365-2958.2009. 06935.x

Kime, L., Vincent, H. A., Gendoo, D. M., Jourdan, S. S., Fishwick, C. W., Callaghan, A. J., et al. (2015). The first small-molecule inhibitors of members of the ribonuclease E family. Sci. Rep. 5:8028. doi: 10.1038/srep08028

Kinghorn, S. M., O’Byrne, C. P., Booth, I. R., and Stansfield, I. (2002). Physiological analysis of the role of truB in Escherichia coli: a role for tRNA modification in extreme temperature resistance. Microbiology 148(Pt 11), 3511-3520. doi: 10.1099/00221287-148-11-3511

Klug, G., and Cohen, S. N. (1990). Combined actions of multiple hairpin loop structures and sites of rate-limiting endonucleolytic cleavage determine differential degradation rates of individual segments within polycistronic puf operon mRNA. J. Bacteriol. 172, 5140-5146. doi: 10.1128/jb.172.9.5140-5146. 1990

Kowtoniuk, W. E., Shen, Y., Heemstra, J. M., Agarwal, I., and Liu, D. R. (2009). A chemical screen for biological small molecule-RNA conjugates reveals CoAlinked RNA. Proc. Natl. Acad. Sci. U.S.A. 106, 7768-7773. doi: 10.1073/pnas. 0900528106

Krishnan, S., Petchiappan, A., Singh, A., Bhatt, A., and Chatterji, D. (2016). Rloop induced stress response by second (p)ppGpp synthetase in Mycobacterium smegmatis: functional and domain interdependence. Mol. Microbiol. 102, 168182. doi: $10.1111 / \mathrm{mmi} .13453$

Kristoffersen, S. M., Haase, C., Weil, M. R., Passalacqua, K. D., Niazi, F., Hutchison, S. K., et al. (2012). Global mRNA decay analysis at single nucleotide resolution reveals segmental and positional degradation patterns in a Gram-positive bacterium. Genome Biol. 13:R30. doi: 10.1186/gb-2012-13-4-r30
Kumar, A., Majid, M., Kunisch, R., Rani, P. S., Qureshi, I. A., Lewin, A., et al. (2012). Mycobacterium tuberculosis DosR regulon gene Rv0079 encodes a putative, 'dormancy associated translation inhibitor (DATIN)'. PLoS One 7:e38709. doi: 10.1371/journal.pone.0038709

Laxman, S., Sutter, B. M., Wu, X., Kumar, S., Guo, X., Trudgian, D. C., et al. (2013). Sulfur amino acids regulate translational capacity and metabolic homeostasis through modulation of tRNA thiolation. Cell 154, 416-429. doi: 10.1016/j.cell. 2013.06.043

Lee, E. J., and Groisman, E. A. (2010). An antisense RNA that governs the expression kinetics of a multifunctional virulence gene. Mol. Microbiol. 76, 1020-1033. doi: 10.1111/j.1365-2958.2010.07161.x

Lee, K., Zhan, X., Gao, J., Qiu, J., Feng, Y., Meganathan, R., et al. (2003). RraA. a protein inhibitor of RNase E activity that globally modulates RNA abundance in E. coli. Cell 114, 623-634.

Lee, P. C., Bochner, B. R., and Ames, B. N. (1983). AppppA, heat-shock stress, and cell oxidation. Proc. Natl. Acad. Sci. U.S.A. 80, 7496-7500. doi: 10.1073/pnas.80. 24.7496

Lehnik-Habrink, M., Newman, J., Rothe, F. M., Solovyova, A. S., Rodrigues, C. Herzberg, C., et al. (2011). RNase Y in Bacillus subtilis: a Natively disordered protein that is the functional equivalent of RNase E from Escherichia coli. J. Bacteriol. 193, 5431-5441. doi: 10.1128/JB.05500-11

Lehnik-Habrink, M., Pfortner, H., Rempeters, L., Pietack, N., Herzberg, C., and Stulke, J. (2010). The RNA degradosome in Bacillus subtilis: identification of CshA as the major RNA helicase in the multiprotein complex. Mol. Microbiol. 77, 958-971. doi: 10.1111/j.1365-2958.2010.07264.x

Leimeister-Wachter, M., Domann, E., and Chakraborty, T. (1991). Detection of a gene encoding a phosphatidylinositol-specific phospholipase $\mathrm{C}$ that is co-ordinately expressed with listeriolysin in Listeria monocytogenes. Mol. Microbiol. 5, 361-366. doi: 10.1111/j.1365-2958.1991.tb02 117.x

Leimeister-Wachter, M., Haffner, C., Domann, E., Goebel, W., and Chakraborty, T. (1990). Identification of a gene that positively regulates expression of listeriolysin, the major virulence factor of Listeria monocytogenes. Proc. Natl. Acad. Sci. U.S.A. 87, 8336-8340. doi: 10.1073/pnas.87.21.8336

Lenz, G., Doron-Faigenboim, A., Ron, E. Z., Tuller, T., and Gophna, U. (2011). Sequence features of E. coli mRNAs affect their degradation. PLoS One 6:e28544. doi: 10.1371/journal.pone.0028544

Li, Z., Pandit, S., and Deutscher, M. P. (1998). Polyadenylation of stable RNA precursors in vivo. Proc. Natl. Acad. Sci. U.S.A. 95, 12158-12162. doi: 10.1073/ pnas.95.21.12158

Liang, W., and Deutscher, M. P. (2013). Ribosomes regulate the stability and action of the exoribonuclease RNase R. J. Biol. Chem. 288, 34791-34798. doi: 10.1074/jbc.M113.519553

Linder, B., Grozhik, A. V., Olarerin-George, A. O., Meydan, C., Mason, C. E., and Jaffrey, S. R. (2015). Single-nucleotide-resolution mapping of m6A and m6Am throughout the transcriptome. Nat. Methods 12, 767-772. doi: 10.1038/nmeth. 3453

Liu, M. Y., Gui, G., Wei, B., Preston, J. F. III, Oakford, L., Yuksel, U., et al. (1997). The RNA molecule CsrB binds to the global regulatory protein CsrA and antagonizes its activity in Escherichia coli. J. Biol. Chem. 272, 17502-17510. doi: 10.1074/jbc.272.28.17502

Liu, M. Y., Yang, H., and Romeo, T. (1995). The product of the pleiotropic Escherichia coli gene csrA modulates glycogen biosynthesis via effects on mRNA stability. J. Bacteriol. 177, 2663-2672. doi: 10.1128/jb.177.10.2663-2672. 1995

Liu, Y., Wu, N., Dong, J., Gao, Y., Zhang, X., Mu, C., et al. (2010). Hfq is a global regulator that controls the pathogenicity of Staphylococcus aureus. PLoS One 5:e13069. doi: 10.1371/journal.pone.0013069

Loh, E., Dussurget, O., Gripenland, J., Vaitkevicius, K., Tiensuu, T., Mandin, P., et al. (2009). A trans-acting riboswitch controls expression of the virulence regulator PrfA in Listeria monocytogenes. Cell 139, 770-779. doi: 10.1016/j.cell. 2009.08.046

Loh, E., Memarpour, F., Vaitkevicius, K., Kallipolitis, B. H., Johansson, J., and Sonden, B. (2012). An unstructured $5^{\prime}$-coding region of the prfA mRNA is required for efficient translation. Nucleic Acids Res. 40, 1818-1827. doi: 10.1093/ nar/gkr850

Lopez, P. J., Marchand, I., Joyce, S. A., and Dreyfus, M. (1999). The C-terminal half of RNase E, which organizes the Escherichia coli degradosome, participates 
in mRNA degradation but not rRNA processing in vivo. Mol. Microbiol. 33, 188-199. doi: 10.1046/j.1365-2958.1999.01465.x

Lopez, P. J., Marchand, I., Yarchuk, O., and Dreyfus, M. (1998). Translation inhibitors stabilize Escherichia coli mRNAs independently of ribosome protection. Proc. Natl. Acad. Sci. U.S.A. 95, 6067-6072. doi: 10.1073/pnas.95. 11.6067

Luciano, D. J., and Belasco, J. G. (2020). Np4A alarmones function in bacteria as precursors to RNA caps. Proc. Natl. Acad. Sci. U.S.A. 117, 3560-3567. doi: 10.1073/pnas.1914229117

Luciano, D. J., Levenson-Palmer, R., and Belasco, J. G. (2019). Stresses that raise Np4A levels induce protective nucleoside tetraphosphate capping of bacterial RNA. Mol. Cell 75, 957-966.e8. doi: 10.1016/j.molcel.2019.05.031

Luciano, D. J., Vasilyev, N., Richards, J., Serganov, A., and Belasco, J. G. (2017). A novel RNA phosphorylation state enables $5^{\prime}$ end-dependent degradation in Escherichia coli. Mol. Cell 67, 44-54.e6. doi: 10.1016/j.molcel.2017.05.035

Ludwig, H., Homuth, G., Schmalisch, M., Dyka, F. M., Hecker, M., and Stulke, J. (2001). Transcription of glycolytic genes and operons in Bacillus subtilis: evidence for the presence of multiple levels of control of the gapA operon. Mol. Microbiol. 41, 409-422. doi: 10.1046/j.1365-2958.2001.02523.x

Lundberg, U., von Gabain, A., and Melefors, O. (1990). Cleavages in the $5^{\prime}$ region of the ompA and bla mRNA control stability: studies with an E. coli mutant altering mRNA stability and a novel endoribonuclease. EMBO J. 9, 2731-2741. doi: 10.1002/j.1460-2075.1990.tb07460.x

Mackie, G. A. (1992). Secondary structure of the mRNA for ribosomal protein S20. Implications for cleavage by ribonuclease E. J. Biol. Chem. 267, 1054-1061.

Mackie, G. A. (1998). Ribonuclease E is a $5^{\prime}$-end-dependent endonuclease. Nature 395, 720-723. doi: 10.1038/27246

Maggi, N., Pasqualucci, C. R., Ballotta, R., and Sensi, P. (1966). Rifampicin: a new orally active rifamycin. Chemotherapy 11, 285-292. doi: 10.1159/000220462

Marcaida, M. J., DePristo, M. A., Chandran, V., Carpousis, A. J., and Luisi, B. F. (2006). The RNA degradosome: life in the fast lane of adaptive molecular evolution. Trends Biochem. Sci. 31, 359-365. doi: 10.1016/j.tibs.2006.05.005

Martinez, I., El-Said Mohamed, M., Santos, V. E., Garcia, J. L., Garcia-Ochoa, F., and Diaz, E. (2017). Metabolic and process engineering for biodesulfurization in Gram-negative bacteria. J. Biotechnol. 262, 47-55. doi: 10.1016/j.jbiotec.2017. 09.004

Martinez-Costa, O. H., Fernandez-Moreno, M. A., and Malpartida, F. (1998). The relA/spoT-homologous gene in Streptomyces coelicolor encodes both ribosomedependent (p)ppGpp-synthesizing and-degrading activities. J. Bacteriol. 180, 4123-4132. doi: 10.1128/jb.180.16.4123-4132.1998

Martini, M. C., Zhou, Y., Sun, H., and Shell, S. S. (2019). Defining the transcriptional and post-transcriptional landscapes of Mycobacterium smegmatis in aerobic growth and hypoxia. Front. Microbiol. 10:591. doi: 10. 3389/fmicb.2019.00591

Mathy, N., Hebert, A., Mervelet, P., Benard, L., Dorleans, A., Li de la Sierra-Gallay, I., et al. (2010). Bacillus subtilis ribonucleases J1 and J2 form a complex with altered enzyme behaviour. Mol. Microbiol. 75, 489-498. doi: 10.1111/j.13652958.2009.07004.x

Matsunaga, J., Simons, E. L., and Simons, R. W. (1996). RNase III autoregulation: structure and function of $\mathrm{rncO}$, the posttranscriptional "operator". RNA 2, $1228-1240$.

Matsunaga, J., Simons, E. L., and Simons, R. W. (1997). Escherichia coli RNase III (rnc) autoregulation occurs independently of rnc gene translation. Mol. Microbiol. 26, 1125-1135. doi: 10.1046/j.1365-2958.1997.6652007.x

McDowall, K. J., Kaberdin, V. R., Wu, S. W., Cohen, S. N., and Lin-Chao, S. (1995). Site-specific RNase E cleavage of oligonucleotides and inhibition by stem-loops. Nature 374, 287-290. doi: 10.1038/374287a0

McDowall, K. J., Lin-Chao, S., and Cohen, S. N. (1994). A+U content rather than a particular nucleotide order determines the specificity of RNase E cleavage. J. Biol. Chem. 269, 10790-10796.

McLaren, R. S., Newbury, S. F., Dance, G. S., Causton, H. C., and Higgins, C. F. (1991). mRNA degradation by processive $3^{\prime}-5^{\prime}$ exoribonucleases in vitro and the implications for prokaryotic mRNA decay in vivo. J. Mol. Biol. 221, 81-95. doi: 10.1016/0022-2836(91)90806-h

Melin, L., Rutberg, L., and von Gabain, A. (1989). Transcriptional and posttranscriptional control of the Bacillus subtilis succinate dehydrogenase operon. J. Bacteriol. 171, 2110-2115. doi: 10.1128/jb.171.4.2110-2115.1989
Messing, S. A., Gabelli, S. B., Liu, Q., Celesnik, H., Belasco, J. G., Pineiro, S. A., et al. (2009). Structure and biological function of the RNA pyrophosphohydrolase BdRppH from Bdellovibrio bacteriovorus. Structure 17, 472-481. doi: 10.1016/j. str.2008.12.022

Meyer, K. D., Saletore, Y., Zumbo, P., Elemento, O., Mason, C. E., and Jaffrey, S. R. (2012). Comprehensive analysis of mRNA methylation reveals enrichment in $3^{\prime}$ UTRs and near stop codons. Cell 149, 1635-1646. doi: 10.1016/j.cell.2012. 05.003

Moffitt, J. R., Pandey, S., Boettiger, A. N., Wang, S., and Zhuang, X. (2016). Spatial organization shapes the turnover of a bacterial transcriptome. eLife 5:e13065. doi: 10.7554/eLife.13065

Mohanty, B. K., and Kushner, S. R. (2000). Polynucleotide phosphorylase functions both as a $3^{\prime}$ right-arrow $5^{\prime}$ exonuclease and a poly(A) polymerase in Escherichia coli. Proc. Natl. Acad. Sci. U.S.A. 97, 11966-11971. doi: 10.1073/pnas.220295997

Mohanty, B. K., and Kushner, S. R. (2002). Polyadenylation of Escherichia coli transcripts plays an integral role in regulating intracellular levels of polynucleotide phosphorylase and RNase E. Mol. Microbiol. 45, 1315-1324. doi: 10.1046/j.1365-2958.2002.03097.x

Moll, I., Afonyushkin, T., Vytvytska, O., Kaberdin, V. R., and Blasi, U. (2003). Coincident Hfq binding and RNase E cleavage sites on mRNA and small regulatory RNAs. RNA 9, 1308-1314. doi: 10.1261/rna.5850703

Moller, T., Franch, T., Hojrup, P., Keene, D. R., Bachinger, H. P., Brennan, R. G., et al. (2002). Hfq: a bacterial Sm-like protein that mediates RNA-RNA interaction. Mol. Cell 9, 23-30. doi: 10.1016/s1097-2765(01)00436-1

Montero Llopis, P., Jackson, A. F., Sliusarenko, O., Surovtsev, I., Heinritz, J., Emonet, T., et al. (2010). Spatial organization of the flow of genetic information in bacteria. Nature 466, 77-81. doi: 10.1038/nature09152

Morin, M., Enjalbert, B., Ropers, D., Girbal, L., and Cocaign-Bousquet, M. (2020). Genomewide Stabilization of mRNA during a "Feast-to-Famine" Growth Transition in Escherichia coli. mSphere 5:e00276-20. doi: 10.1128/mSphere. 00276-20

Morita, T., and Aiba, H. (2011). RNase E action at a distance: degradation of target mRNAs mediated by an Hfq-binding small RNA in bacteria. Genes Dev. 25, 294-298. doi: 10.1101/gad.2030311

Morita, T., Kawamoto, H., Mizota, T., Inada, T., and Aiba, H. (2004). Enolase in the RNA degradosome plays a crucial role in the rapid decay of glucose transporter mRNA in the response to phosphosugar stress in Escherichia coli. Mol. Microbiol. 54, 1063-1075. doi: 10.1111/j.1365-2958.2004.04329.x

Morrison, J. M., Anderson, K. L., Beenken, K. E., Smeltzer, M. S., and Dunman, P. M. (2012). The staphylococcal accessory regulator, SarA, is an RNA-binding protein that modulates the mRNA turnover properties of late-exponential and stationary phase Staphylococcus aureus cells. Front. Cell. Infect. Microbiol. 2:26. doi: $10.3389 /$ fcimb.2012.00026

Muller, P., Gimpel, M., Wildenhain, T., and Brantl, S. (2019). A new role for CsrA: promotion of complex formation between an sRNA and its mRNA target in Bacillus subtilis. RNA Biol. 16, 972-987. doi: 10.1080/15476286.2019.1605811

Murashko, O. N., Kaberdin, V. R., and Lin-Chao, S. (2012). Membrane binding of Escherichia coli RNase E catalytic domain stabilizes protein structure and increases RNA substrate affinity. Proc. Natl. Acad. Sci. U.S.A. 109, 7019-7024. doi: 10.1073/pnas.1120181109

Murashko, O. N., and Lin-Chao, S. (2017). Escherichia coli responds to environmental changes using enolasic degradosomes and stabilized DicF sRNA to alter cellular morphology. Proc. Natl. Acad. Sci. U.S.A. 114, E8025-E8034. doi: $10.1073 /$ pnas. 1703731114

Murdeshwar, M. S., and Chatterji, D. (2012). MS_RHII-RSD, a dual-function RNase HII-(p)ppGpp synthetase from Mycobacterium smegmatis. J. Bacteriol. 194, 4003-4014. doi: 10.1128/JB.00258-12

Nakamoto, M. A., Lovejoy, A. F., Cygan, A. M., and Boothroyd, J. C. (2017). mRNA pseudouridylation affects RNA metabolism in the parasite Toxoplasma gondii. RNA 23, 1834-1849. doi: 10.1261/rna.062794.117

Newbury, S. F., Smith, N. H., Robinson, E. C., Hiles, I. D., and Higgins, C. F. (1987). Stabilization of translationally active mRNA by prokaryotic REP sequences. Cell 48, 297-310. doi: 10.1016/0092-8674(87)90433-8

Nguyen, T. G., Vargas-Blanco, D. A., Roberts, L. A., and Shell, S. S. (2020). The impact of leadered and leaderless gene structures on translation efficiency, transcript stability, and predicted transcription rates in Mycobacterium smegmatis. J. Bacteriol. 202:e00746-19. 
Nielsen, J. S., Larsen, M. H., Lillebaek, E. M., Bergholz, T. M., Christiansen, M. H., Boor, K. J., et al. (2011). A small RNA controls expression of the chitinase ChiA in Listeria monocytogenes. PLoS One 6:e19019. doi: 10.1371/journal.pone. 0019019

Nielsen, J. S., Lei, L. K., Ebersbach, T., Olsen, A. S., Klitgaard, J. K., ValentinHansen, P., et al. (2010). Defining a role for Hfq in Gram-positive bacteria: evidence for Hfq-dependent antisense regulation in Listeria monocytogenes. Nucleic Acids Res. 38, 907-919. doi: 10.1093/nar/gkp1081

Nilsson, G., Belasco, J. G., Cohen, S. N., and von Gabain, A. (1984). Growth-rate dependent regulation of mRNA stability in Escherichia coli. Nature 312, 75-77. doi: $10.1038 / 312075 \mathrm{a} 0$

Nilsson, P., Naureckiene, S., and Uhlin, B. E. (1996). Mutations affecting mRNA processing and fimbrial biogenesis in the Escherichia coli pap operon. J. Bacteriol. 178, 683-690. doi: 10.1128/jb.178.3.683-690.1996

Nilsson, P., and Uhlin, B. E. (1991). Differential decay of a polycistronic Escherichia coli transcript is initiated by RNaseE-dependent endonucleolytic processing. Mol. Microbiol. 5, 1791-1799. doi: 10.1111/j.1365-2958.1991.tb01928.x

Nishikura, K., and De Robertis, E. M. (1981). RNA processing in microinjected Xenopus oocytes. Sequential addition of base modifications in the spliced transfer RNA. J. Mol. Biol. 145, 405-420. doi: 10.1016/0022-2836(81)90212-6

Nouaille, S., Mondeil, S., Finoux, A. L., Moulis, C., Girbal, L., and CocaignBousquet, M. (2017). The stability of an mRNA is influenced by its concentration: a potential physical mechanism to regulate gene expression. Nucleic Acids Res. 45, 11711-11724. doi: 10.1093/nar/gkx781

Nurse, K., Wrzesinski, J., Bakin, A., Lane, B. G., and Ofengand, J. (1995). Purification, cloning, and properties of the tRNA psi 55 synthase from Escherichia coli. RNA 1, 102-112.

Olson, P. D., Kuechenmeister, L. J., Anderson, K. L., Daily, S., Beenken, K. E., Roux, C. M., et al. (2011). Small molecule inhibitors of Staphylococcus aureus RnpA alter cellular mRNA turnover, exhibit antimicrobial activity, and attenuate pathogenesis. PLoS Pathog. 7:e1001287. doi: 10.1371/journal.ppat.1001287

Ow, M. C., Liu, Q., and Kushner, S. R. (2000). Analysis of mRNA decay and rRNA processing in Escherichia coli in the absence of RNase E-based degradosome assembly. Mol. Microbiol. 38, 854-866. doi: 10.1046/j.1365-2958.2000.02186.x

Paesold, G., and Krause, M. (1999). Analysis of rpoS mRNA in Salmonella dublin: identification of multiple transcripts with growth-phase-dependent variation in transcript stability. J. Bacteriol. 181, 1264-1268. doi: 10.1128/jb.181.4.12641268.1999

Panneerdoss, S., Eedunuri, V. K., Yadav, P., Timilsina, S., Rajamanickam, S., Viswanadhapalli, S., et al. (2018). Cross-talk among writers, readers, and erasers of $\mathrm{m}(6) \mathrm{A}$ regulates cancer growth and progression. Sci. Adv. 4:eaar8263. doi: 10.1126/sciadv.aar8263

Papenfort, K., Pfeiffer, V., Mika, F., Lucchini, S., Hinton, J. C., and Vogel, J. (2006). SigmaE-dependent small RNAs of Salmonella respond to membrane stress by accelerating global omp mRNA decay. Mol. Microbiol. 62, 1674-1688. doi: 10.1111/j.1365-2958.2006.05524.x

Park, H. D., Guinn, K. M., Harrell, M. I., Liao, R., Voskuil, M. I., Tompa, M., et al. (2003). Rv3133c/dosR is a transcription factor that mediates the hypoxic response of Mycobacterium tuberculosis. Mol. Microbiol. 48, 833-843. doi: 10. 1046/j.1365-2958.2003.03474.x

Pato, M. L., Bennett, P. M., and von Meyenburg, K. (1973). Messenger ribonucleic acid synthesis and degradation in Escherichia coli during inhibition of translation. J. Bacteriol. 116, 710-718. doi: 10.1128/jb.116.2.710-718.1973

Pertzev, A. V., and Nicholson, A. W. (2006). Characterization of RNA sequence determinants and antideterminants of processing reactivity for a minimal substrate of Escherichia coli ribonuclease III. Nucleic Acids Res. 34, 3708-3721. doi: 10.1093/nar/gkl459

Petchiappan, A., Naik, S. Y., and Chatterji, D. (2020). RelZ-mediated stress response in Mycobacterium smegmatis: pGpp synthesis and its regulation. J. Bacteriol. 202:e00444-19. doi: 10.1128/JB.00444-19

Plocinski, P., Macios, M., Houghton, J., Niemiec, E., Plocinska, R., Brzostek, A., et al. (2019). Proteomic and transcriptomic experiments reveal an essential role of RNA degradosome complexes in shaping the transcriptome of Mycobacterium tuberculosis. Nucleic Acids Res. 47, 5892-5905. doi: 10.1093/nar/ gkz251

Presnyak, V., Alhusaini, N., Chen, Y. H., Martin, S., Morris, N., Kline, N., et al. (2015). Codon optimality is a major determinant of mRNA stability. Cell 160, 1111-1124. doi: 10.1016/j.cell.2015.02.029
Py, B., Causton, H., Mudd, E. A., and Higgins, C. F. (1994). A protein complex mediating mRNA degradation in Escherichia coli. Mol. Microbiol. 14, 717-729. doi: 10.1111/j.1365-2958.1994.tb01309.x

Py, B., Higgins, C. F., Krisch, H. M., and Carpousis, A. J. (1996). A DEAD-box RNA helicase in the Escherichia coli RNA degradosome. Nature 381, 169-172. doi: 10.1038/381169a0

Quereda, J. J., Andersson, C., Cossart, P., Johansson, J., and Pizarro-Cerda, J. (2018). Role in virulence of phospholipases, listeriolysin O and listeriolysin $\mathrm{S}$ from epidemic Listeria monocytogenes using the chicken embryo infection model. Vet. Res. 49:13. doi: 10.1186/s13567-017-0496-4

Ramirez-Pena, E., Trevino, J., Liu, Z., Perez, N., and Sumby, P. (2010). The group A Streptococcus small regulatory RNA FasX enhances streptokinase activity by increasing the stability of the ska mRNA transcript. Mol. Microbiol. 78, 1332-1347. doi: 10.1111/j.1365-2958.2010.07427.x

Rao, S. P., Alonso, S., Rand, L., Dick, T., and Pethe, K. (2008). The protonmotive force is required for maintaining ATP homeostasis and viability of hypoxic, nonreplicating Mycobacterium tuberculosis. Proc. Natl. Acad. Sci. U.S.A. 105, 11945-11950. doi: 10.1073/pnas.0711697105

Redko, Y., Galtier, E., Arnion, H., Darfeuille, F., Sismeiro, O., Coppee, J. Y., et al. (2016). RNase J depletion leads to massive changes in mRNA abundance in Helicobacter pylori. RNA Biol. 13, 243-253. doi: 10.1080/15476286.2015. 1132141

Redon, E., Loubiere, P., and Cocaign-Bousquet, M. (2005a). Transcriptome analysis of the progressive adaptation of Lactococcus lactis to carbon starvation. J. Bacteriol. 187, 3589-3592. doi: 10.1128/JB.187.10.3589-3592.2005

Redon, E., Loubiere, P., and Cocaign-Bousquet, M. (2005b). Role of mRNA stability during genome-wide adaptation of Lactococcus lactis to carbon starvation. J. Biol. Chem. 280, 36380-36385. doi: 10.1074/jbc.M506006200

Regnier, P., and Hajnsdorf, E. (2013). The interplay of Hfq, poly(A) polymerase I and exoribonucleases at the $3^{\prime}$ ends of RNAs resulting from Rho-independent termination: a tentative model. RNA Biol. 10, 602-609. doi: 10.4161/rna.23664

Richards, J., and Belasco, J. G. (2016). Distinct requirements for $5^{\prime}$ monophosphate-assisted RNA cleavage by Escherichia coli RNase E and RNase G. J. Biol. Chem. 291, 20825. doi: 10.1074/jbc.A115.702555

Richards, J., and Belasco, J. G. (2019). Obstacles to scanning by RNase E govern bacterial mRNA lifetimes by hindering access to distal cleavage sites. Mol. Cell 74, 284-295.e5. doi: 10.1016/j.molcel.2019.01.044

Richards, J., Liu, Q., Pellegrini, O., Celesnik, H., Yao, S., Bechhofer, D. H., et al. (2011). An RNA pyrophosphohydrolase triggers $5^{\prime}$-exonucleolytic degradation of mRNA in Bacillus subtilis. Mol. Cell 43, 940-949. doi: 10.1016/j.molcel.2011. 07.023

Riglar, D. T., Giessen, T. W., Baym, M., Kerns, S. J., Niederhuber, M. J., Bronson, R. T., et al. (2017). Engineered bacteria can function in the mammalian gut long-term as live diagnostics of inflammation. Nat. Biotechnol. 35, 653-658. doi: $10.1038 /$ nbt.3879

Rittershaus, E. S., Baek, S. H., and Sassetti, C. M. (2013). The normalcy of dormancy: common themes in microbial quiescence. Cell Host Microbe 13, 643-651. doi: 10.1016/j.chom.2013.05.012

Roberts, C., Anderson, K. L., Murphy, E., Projan, S. J., Mounts, W., Hurlburt, B., et al. (2006). Characterizing the effect of the Staphylococcus aureus virulence factor regulator, SarA, on log-phase mRNA half-lives. J. Bacteriol. 188, 25932603. doi: 10.1128/JB.188.7.2593-2603.2006

Rochat, T., Bouloc, P., Yang, Q., Bossi, L., and Figueroa-Bossi, N. (2012). Lack of interchangeability of Hfq-like proteins. Biochimie 94, 1554-1559. doi: 10.1016/ j.biochi.2012.01.016

Rochat, T., Delumeau, O., Figueroa-Bossi, N., Noirot, P., Bossi, L., Dervyn, E., et al. (2015). Tracking the elusive function of Bacillus subtilis Hfq. PLoS One 10:e0124977. doi: 10.1371/journal.pone.0124977

Romeo, T., and Babitzke, P. (2018). Global regulation by CsrA and its RNA antagonists. Microbiol. Spectr. 6:10.1128/microbiolspec.RWR-0009-2017.

Ross, J. A., Thorsing, M., Lillebaek, E. M. S., Teixeira Dos Santos, P., and Kallipolitis, B. H. (2019). The LhrC sRNAs control expression of T cellstimulating antigen TcsA in Listeria monocytogenes by decreasing tcsA mRNA stability. RNA Biol. 16, 270-281. doi: 10.1080/15476286.2019.157 2423

Rozenski, J., Crain, P. F., and McCloskey, J. A. (1999). The RNA modification database: 1999 update. Nucleic Acids Res. 27, 196-197. doi: 10.1093/nar/ 27.1.196 
Rustad, T. R., Minch, K. J., Brabant, W., Winkler, J. K., Reiss, D. J., Baliga, N. S., et al. (2013). Global analysis of mRNA stability in Mycobacterium tuberculosis. Nucleic Acids Res. 41, 509-517. doi: 10.1093/nar/gks1019

Sala, C., Forti, F., Magnoni, F., and Ghisotti, D. (2008). The katG mRNA of Mycobacterium tuberculosis and Mycobacterium smegmatis is processed at its $5^{\prime}$ end and is stabilized by both a polypurine sequence and translation initiation. BMC Mol. Biol. 9:33. doi: 10.1186/1471-2199-9-33

Sandler, P., and Weisblum, B. (1989). Erythromycin-induced ribosome stall in the ermA leader: a barricade to $5^{\prime}$-to- $3^{\prime}$ nucleolytic cleavage of the ermA transcript. J. Bacteriol. 171, 6680-6688. doi: 10.1128/jb.171.12.6680-6688.1989

Santiago-Frangos, A., and Woodson, S. A. (2018). Hfq chaperone brings speed dating to bacterial sRNA. Wiley Interdiscip. Rev. RNA 9:e1475. doi: 10.1002/ wrna. 1475

Schneider, E., Blundell, M., and Kennell, D. (1978). Translation and mRNA decay. Mol. Gen. Genet. 160, 121-129.

Schubert, O. T., Ludwig, C., Kogadeeva, M., Zimmermann, M., Rosenberger, G., Gengenbacher, M., et al. (2015). Absolute proteome composition and dynamics during dormancy and resuscitation of Mycobacterium tuberculosis. Cell Host Microbe 18, 96-108. doi: 10.1016/j.chom.2015.06.001

Schumacher, M. A., Pearson, R. F., Moller, T., Valentin-Hansen, P., and Brennan, R. G. (2002). Structures of the pleiotropic translational regulator $\mathrm{Hfq}$ and an Hfq-RNA complex: a bacterial Sm-like protein. EMBO J. 21, 3546-3556. doi: 10.1093/emboj/cdf322

Schumann, U., Zhang, H. N., Sibbritt, T., Pan, A., Horvath, A., Gross, S., et al. (2020). Multiple links between 5-methylcytosine content of mRNA and translation. BMC Biol. 18:40. doi: 10.1186/s12915-020-00769-5

Schwartz, S., Mumbach, M. R., Jovanovic, M., Wang, T., Maciag, K., Bushkin, G. G., et al. (2014). Perturbation of m6A writers reveals two distinct classes of mRNA methylation at internal and $5^{\prime}$ sites. Cell Rep. 8, 284-296. doi: 10.1016/j.celrep. 2014.05.048

Segev, E., Smith, Y., and Ben-Yehuda, S. (2012). RNA dynamics in aging bacterial spores. Cell 148, 139-149. doi: 10.1016/j.cell.2011.11.059

Selinger, D. W., Saxena, R. M., Cheung, K. J., Church, G. M., and Rosenow, C. (2003). Global RNA half-life analysis in Escherichia coli reveals positional patterns of transcript degradation. Genome Res. 13, 216-223. doi: 10.1101/gr. 912603

Seyfzadeh, M., Keener, J., and Nomura, M. (1993). spoT-dependent accumulation of guanosine tetraphosphate in response to fatty acid starvation in Escherichia coli. Proc. Natl. Acad. Sci. U.S.A. 90, 11004-11008. doi: 10.1073/pnas.90.23. 11004

Shahbabian, K., Jamalli, A., Zig, L., and Putzer, H. (2009). RNase Y, a novel endoribonuclease, initiates riboswitch turnover in Bacillus subtilis. EMBO J. 28, 3523-3533. doi: 10.1038/emboj.2009.283

Shalem, O., Dahan, O., Levo, M., Martinez, M. R., Furman, I., Segal, E., et al. (2008). Transient transcriptional responses to stress are generated by opposing effects of mRNA production and degradation. Mol. Syst. Biol. 4:223. doi: 10.1038/msb. 2008.59

Sharp, J. S., and Bechhofer, D. H. (2005). Effect of $5^{\prime}$-proximal elements on decay of a model mRNA in Bacillus subtilis. Mol. Microbiol. 57, 484-495. doi: 10.1111/ j.1365-2958.2005.04683.x

Sherman, D. R., Voskuil, M., Schnappinger, D., Liao, R., Harrell, M. I., and Schoolnik, G. K. (2001). Regulation of the Mycobacterium tuberculosis hypoxic response gene encoding alpha -crystallin. Proc. Natl. Acad. Sci. U.S.A. 98, 7534-7539. doi: 10.1073/pnas.121172498

Shivakumar, A. G., Hahn, J., Grandi, G., Kozlov, Y., and Dubnau, D. (1980). Posttranscriptional regulation of an erythromycin resistance protein specified by plasmic pE194. Proc. Natl. Acad. Sci. U.S.A. 77, 3903-3907. doi: 10.1073/ pnas.77.7.3903

Siculella, L., Damiano, F., di Summa, R., Tredici, S. M., Alduina, R., Gnoni, G. V., et al. (2010). Guanosine $5^{\prime}$-diphosphate $3^{\prime}$-diphosphate (ppGpp) as a negative modulator of polynucleotide phosphorylase activity in a 'rare' actinomycete. Mol. Microbiol. 77, 716-729. doi: 10.1111/j.1365-2958.2010.07240.x

Sievers, S., Lund, A., Menendez-Gil, P., Nielsen, A., Storm Mollerup, M., Lambert Nielsen, S., et al. (2015). The multicopy sRNA LhrC controls expression of the oligopeptide-binding protein OppA in Listeria monocytogenes. RNA Biol. 12, 985-997. doi: 10.1080/15476286.2015.1071011

Silva, A. J., Sultan, S. Z., Liang, W., and Benitez, J. A. (2008). Role of the histonelike nucleoid structuring protein in the regulation of rpoS and RpoS-dependent genes in Vibrio cholerae. J. Bacteriol. 190, 7335-7345. doi: 10.1128/JB. 00360-08

Sim, M., Lim, B., Sim, S. H., Kim, D., Jung, E., Lee, Y., et al. (2014). Two tandem RNase III cleavage sites determine betT mRNA stability in response to osmotic stress in Escherichia coli. PLoS One 9:e100520. doi: 10.1371/journal. pone. 0100520

Sinha, D., Matz, L. M., Cameron, T. A., and De Lay, N. R. (2018). Poly(A) polymerase is required for RyhB sRNA stability and function in Escherichia coli. RNA 24, 1496-1511. doi: 10.1261/rna.067181.118

Sittka, A., Lucchini, S., Papenfort, K., Sharma, C. M., Rolle, K., Binnewies, T. T., et al. (2008). Deep sequencing analysis of small noncoding RNA and mRNA targets of the global post-transcriptional regulator, Hfq. PLoS Genet. 4:e1000163. doi: 10.1371/journal.pgen.1000163

Smeulders, M. J., Keer, J., Speight, R. A., and Williams, H. D. (1999). Adaptation of Mycobacterium smegmatis to stationary phase. J. Bacteriol. 181, 270-283. doi: 10.1128/jb.181.1.270-283.1999

Sonnleitner, E., Schuster, M., Sorger-Domenigg, T., Greenberg, E. P., and Blasi, U. (2006). Hfq-dependent alterations of the transcriptome profile and effects on quorum sensing in Pseudomonas aeruginosa. Mol. Microbiol. 59, 1542-1558. doi: 10.1111/j.1365-2958.2006.05032.x

Sousa, S., Marchand, I., and Dreyfus, M. (2001). Autoregulation allows Escherichia coli RNase E to adjust continuously its synthesis to that of its substrates. Mol. Microbiol. 42, 867-878. doi: 10.1046/j.1365-2958.2001.02687.x

Steglich, C., Lindell, D., Futschik, M., Rector, T., Steen, R., and Chisholm, S. W. (2010). Short RNA half-lives in the slow-growing marine cyanobacterium Prochlorococcus. Genome Biol. 11:R54. doi: 10.1186/gb-2010-11-5-r54

Strahl, H., Turlan, C., Khalid, S., Bond, P. J., Kebalo, J. M., Peyron, P., et al. (2015). Membrane recognition and dynamics of the RNA degradosome. PLoS Genet. 11:e1004961. doi: 10.1371/journal.pgen.1004961

Sun, X., Zhulin, I., and Wartell, R. M. (2002). Predicted structure and phyletic distribution of the RNA-binding protein Hfq. Nucleic Acids Res. 30, 3662-3671. doi: 10.1093/nar/gkf508

Tao, F., Liu, Y., Luo, Q., Su, F., Xu, Y., Li, F., et al. (2011). Novel organic solventresponsive expression vectors for biocatalysis: application for development of an organic solvent-tolerant biodesulfurizing strain. Bioresour. Technol. 102, 9380-9387. doi: 10.1016/j.biortech.2011.08.015

Tejada-Arranz, A., de Crecy-Lagard, V., and de Reuse, H. (2020). Bacterial RNA Degradosomes: molecular machines under tight control. Trends Biochem. Sci. 45, 42-57. doi: 10.1016/j.tibs.2019.10.002

Thorne, S. H., and Williams, H. D. (1997). Adaptation to nutrient starvation in Rhizobium leguminosarum bv. phaseoli: analysis of survival, stress resistance, and changes in macromolecular synthesis during entry to and exit from stationary phase. J. Bacteriol. 179, 6894-6901. doi: 10.1128/jb.179.22.68946901.1997

Timmermans, J., and Van Melderen, L. (2010). Post-transcriptional global regulation by CsrA in bacteria. Cell. Mol. Life Sci. 67, 2897-2908. doi: 10.1007/ s00018-010-0381-z

Toledo-Arana, A., Dussurget, O., Nikitas, G., Sesto, N., Guet-Revillet, H., Balestrino, D., et al. (2009). The Listeria transcriptional landscape from saprophytism to virulence. Nature 459, 950-956. doi: 10.1038/nature08080

Tortosa, P., Albano, M., and Dubnau, D. (2000). Characterization of ylbF, a new gene involved in competence development and sporulation in Bacillus subtilis. Mol. Microbiol. 35, 1110-1119. doi: 10.1046/j.1365-2958.2000.01779.x

Udekwu, K. I., Darfeuille, F., Vogel, J., Reimegard, J., Holmqvist, E., and Wagner, E. G. (2005). Hfq-dependent regulation of OmpA synthesis is mediated by an antisense RNA. Genes Dev. 19, 2355-2366. doi: 10.1101/gad.354405

Unciuleac, M. C., and Shuman, S. (2013). Distinctive effects of domain deletions on the manganese-dependent DNA polymerase and DNA phosphorylase activities of Mycobacterium smegmatis polynucleotide phosphorylase. Biochemistry 52, 2967-2981. doi: 10.1021/bi400281w

Unniraman, S., Chatterji, M., and Nagaraja, V. (2002). A hairpin near the $5^{\prime}$ end stabilises the DNA gyrase mRNA in Mycobacterium smegmatis. Nucleic Acids Res. 30, 5376-5381. doi: 10.1093/nar/gkf697

Updegrove, T. B., Zhang, A., and Storz, G. (2016). Hfq: the flexible RNA matchmaker. Curr. Opin. Microbiol. 30, 133-138. doi: 10.1016/j.mib.2016. 02.003

Vanderpool, C. K., and Gottesman, S. (2004). Involvement of a novel transcriptional activator and small RNA in post-transcriptional regulation of 
the glucose phosphoenolpyruvate phosphotransferase system. Mol. Microbiol. 54, 1076-1089. doi: 10.1111/j.1365-2958.2004.04348.x

Vanzo, N. F., Li, Y. S., Py, B., Blum, E., Higgins, C. F., Raynal, L. C., et al. (1998). Ribonuclease E organizes the protein interactions in the Escherichia coli RNA degradosome. Genes Dev. 12, 2770-2781. doi: 10.1101/gad.12.17.2770

Vargas-Blanco, D. A., Zhou, Y., Zamalloa, L. G., Antonelli, T., and Shell, S. S. (2019). mRNA degradation rates are coupled to metabolic status in Mycobacterium smegmatis. mBio 10:e0957-19. doi: 10.1128/mBio.009 57-19

Varmus, H. E., Perlman, R. L., and Pastan, I. (1971). Regulation of lac transcription in antibiotic-treated E. coli. Nat. New Biol. 230, 41-44. doi: 10. 1038/newbio230041a0

Vecerek, B., Rajkowitsch, L., Sonnleitner, E., Schroeder, R., and Blasi, U. (2008). The C-terminal domain of Escherichia coli $\mathrm{Hfq}$ is required for regulation. Nucleic Acids Res. 36, 133-143. doi: 10.1093/nar/gkm985

Ventola, C. L. (2015a). The antibiotic resistance crisis: part 1: causes and threats. $P$ $T 40,277-283$.

Ventola, C. L. (2015b). The antibiotic resistance crisis: part 2: management strategies and new agents. $P$ T 40, 344-352.

Vogel, J., and Luisi, B. F. (2011). Hfq and its constellation of RNA. Nat. Rev. Microbiol. 9, 578-589. doi: 10.1038/nrmicro2615

Vvedenskaya, I. O., Bird, J. G., Zhang, Y., Zhang, Y., Jiao, X., Barvik, I., et al. (2018). CapZyme-seq comprehensively defines promoter-sequence determinants for rna $5^{\prime}$ capping with NAD. Mol. Cell 70, 553-564.e9. doi: 10.1016/j.molcel.2018. 03.014

Vvedenskaya, I. O., Sharp, J. S., Goldman, S. R., Kanabar, P. N., Livny, J., Dove, S. L., et al. (2012). Growth phase-dependent control of transcription start site selection and gene expression by nanoRNAs. Genes Dev. 26, 1498-1507. doi: 10.1101/gad.192732.112

Vytvytska, O., Moll, I., Kaberdin, V. R., von Gabain, A., and Blasi, U. (2000). Hfq (HF1) stimulates ompA mRNA decay by interfering with ribosome binding. Genes Dev. 14, 1109-1118.

Wagner, L. A., Gesteland, R. F., Dayhuff, T. J., and Weiss, R. B. (1994). An efficient Shine-Dalgarno sequence but not translation is necessary for lacZ mRNA stability in Escherichia coli. J. Bacteriol. 176, 1683-1688. doi: 10.1128/jb.176.6. 1683-1688.1994

Wang, H., Ayala, J. C., Benitez, J. A., and Silva, A. J. (2012). Interaction of the histone-like nucleoid structuring protein and the general stress response regulator RpoS at Vibrio cholerae promoters that regulate motility and hemagglutinin/protease expression. J. Bacteriol. 194, 1205-1215. doi: 10.1128/ JB.05900- 11

Wang, X., Dubey, A. K., Suzuki, K., Baker, C. S., Babitzke, P., and Romeo, T. (2005). CsrA post-transcriptionally represses pga $\mathrm{ABCD}$, responsible for synthesis of a biofilm polysaccharide adhesin of Escherichia coli. Mol. Microbiol. 56, 16481663. doi: 10.1111/j.1365-2958.2005.04648.x

Wang, Y., Li, Y., Toth, J. I., Petroski, M. D., Zhang, Z., and Zhao, J. C. (2014). N6-methyladenosine modification destabilizes developmental regulators in embryonic stem cells. Nat. Cell Biol. 16, 191-198. doi: 10.1038/ncb2902

Wassarman, K. M., Repoila, F., Rosenow, C., Storz, G., and Gottesman, S. (2001). Identification of novel small RNAs using comparative genomics and microarrays. Genes Dev. 15, 1637-1651. doi: 10.1101/gad.901001

Wei, B. L., Brun-Zinkernagel, A. M., Simecka, J. W., Pruss, B. M., Babitzke, P., and Romeo, T. (2001). Positive regulation of motility and flhDC expression by the RNA-binding protein CsrA of Escherichia coli. Mol. Microbiol. 40, 245-256. doi: 10.1046/j.1365-2958.2001.02380.x

Wei, C. M., Gershowitz, A., and Moss, B. (1975). Methylated nucleotides block $5^{\prime}$ terminus of HeLa cell messenger RNA. Cell 4, 379-386. doi: 10.1016/00928674(75)90158-0

Wolfe, A. D., and Hahn, F. E. (1965). Mode of action of chloramphenicol. Ix. Effects of chloramphenicol upon a ribosomal amino acid polymerization system and its binding to bacterial ribosome. Biochim. Biophys. Acta 95, 146-155. doi: 10.1016/0005-2787(65)90219-4
Wood, D. N., Chaussee, M. A., Chaussee, M. S., and Buttaro, B. A. (2005). Persistence of Streptococcus pyogenes in stationary-phase cultures. J. Bacteriol. 187, 3319-3328. doi: 10.1128/JB.187.10.3319-3328.2005

World Health Organization [WHO] (2019). No Time to Wait: Securing the Future from Drug-Resistant Infections. Available online at: https://www.who.int/ antimicrobial-resistance/interagency-coordination-group/final-report/en/ (accessed April 17, 2020).

Xu, C., Huang, R., Teng, L., Jing, X., Hu, J., Cui, G., et al. (2015). Cellulosome stoichiometry in Clostridium cellulolyticum is regulated by selective RNA processing and stabilization. Nat. Commun. 6:6900. doi: 10.1038/ncomms 7900

Xu, W., Huang, J., and Cohen, S. N. (2008). Autoregulation of AbsB (RNase III) expression in Streptomyces coelicolor by endoribonucleolytic cleavage of absB operon transcripts. J. Bacteriol. 190, 5526-5530. doi: 10.1128/JB.00558-08

Yang, Y., Wang, L., Han, X., Yang, W. L., Zhang, M., Ma, H. L., et al. (2019). RNA 5-methylcytosine facilitates the maternal-to-zygotic transition by preventing maternal mRNA Decay. Mol. Cell 75, 1188-1202.e11. doi: 10.1016/j.molcel. 2019.06.033

Yarmolinsky, M. B., and Haba, G. L. (1959). Inhibition by puromycin of amino acid incorporation into protein. Proc. Natl. Acad. Sci. U.S.A. 45, 1721-1729. doi: 10.1073/pnas.45.12.1721

Yu, X., Li, B., Jang, G. J., Jiang, S., Jiang, D., Jang, J. C., et al. (2019). Orchestration of Processing body dynamics and mrna decay in Arabidopsis immunity. Cell Rep. 28, 2194-2205.e6. doi: 10.1016/j.celrep.2019.07.054

Yue, Y., Liu, J., Cui, X., Cao, J., Luo, G., Zhang, Z., et al. (2018). VIRMA mediates preferential m(6)A mRNA methylation in $3^{\prime} \mathrm{UTR}$ and near stop codon and associates with alternative polyadenylation. Cell Discov. 4:10. doi: 10.1038/ s41421-018-0019-0

Zeller, M. E., Csanadi, A., Miczak, A., Rose, T., Bizebard, T., and Kaberdin, V. R. (2007). Quaternary structure and biochemical properties of mycobacterial RNase E/G. Biochem. J. 403, 207-215. doi: 10.1042/BJ20061530

Zgurskaya, H. I., Keyhan, M., and Matin, A. (1997). The sigma S level in starving Escherichia coli cells increases solely as a result of its increased stability, despite decreased synthesis. Mol. Microbiol. 24, 643-651. doi: 10.1046/j.1365-2958. 1997.3961742.x

Zhang, A., Wassarman, K. M., Rosenow, C., Tjaden, B. C., Storz, G., and Gottesman, S. (2003). Global analysis of small RNA and mRNA targets of Hfq. Mol. Microbiol. 50, 1111-1124. doi: 10.1046/j.1365-2958.2003.03734.x

Zhang, D., Liu, Y., Wang, Q., Guan, Z., Wang, J., Liu, J., et al. (2016). Structural basis of prokaryotic NAD-RNA decapping by NudC. Cell Res. 26, 1062-1066. doi: $10.1038 / \mathrm{cr} .2016 .98$

Zhang, H., Li, D., Zhao, L., Fleming, J., Lin, N., Wang, T., et al. (2013). Genome sequencing of 161 Mycobacterium tuberculosis isolates from China identifies genes and intergenic regions associated with drug resistance. Nat. Genet. 45, 1255-1260. doi: 10.1038/ng.2735

Zhao, B. S., Wang, X., Beadell, A. V., Lu, Z., Shi, H., Kuuspalu, A., et al. (2017). $\mathrm{m}(6) \mathrm{A}$-dependent maternal mRNA clearance facilitates zebrafish maternal-tozygotic transition. Nature 542, 475-478. doi: 10.1038/nature21355

Zhao, J. P., Zhu, H., Guo, X. P., and Sun, Y. C. (2018). AU-rich long 3' untranslated region regulates gene expression in bacteria. Front. Microbiol. 9:3080. doi: 10. 3389/fmicb.2018.03080

Conflict of Interest: The authors declare that the research was conducted in the absence of any commercial or financial relationships that could be construed as a potential conflict of interest.

Copyright $\odot 2020$ Vargas-Blanco and Shell. This is an open-access article distributed under the terms of the Creative Commons Attribution License (CC BY). The use, distribution or reproduction in other forums is permitted, provided the original author(s) and the copyright owner(s) are credited and that the original publication in this journal is cited, in accordance with accepted academic practice. No use, distribution or reproduction is permitted which does not comply with these terms. 